\title{
Social-ecological networks and connectivity within and between two communities of small-scale fishers in Mexico
}

\author{
$\underline{A d r i a n}$ Munguia-Vega $^{1,2}, \underline{\text { Jose Alberto Zepeda-Dominguez }}^{3}, \underline{\text { Maria Fernanda Perez-Alarcon }}^{4,5}$, Imelda G. Amador-Castro $^{4}, \underline{\text { Stuart }}^{4}$

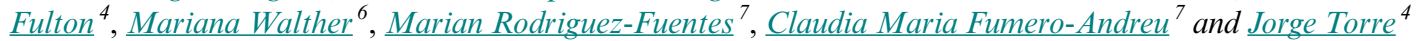

\begin{abstract}
Aligning the ecological and social dimensions of the connections present between users that harvest a shared natural resource is a necessary step toward sustainable management. However, contrasting estimates of connectivity across disciplines is a challenging task and few empirical studies have focused on population dynamics within fish species with a complex life history. We used a collaborative approach merging citizen science, population genetics, oceanographic modeling, and interviews to collect empirical connectivity data of individual fish, fishing sites, and fishers. We integrated the data within a multilevel social-ecological network framework describing the interactions between two communities of small-scale fishers (Bahia Kino and Puerto Libertad, Sonora, Mexico) targeting leopard grouper (Mycteroperca rosacea). We identified two types of social-ecological links, including the use of specific fishing sites by individual fishers and the harvest of individual fish by individual fishers. Despite their fishing zones not overlapping, the ecological links between two communities located $\sim 150 \mathrm{~km}$ apart were consistent and reciprocal where fishing grounds from each community acted as a source of fish to the other during the larval or juvenile/adult stages, respectively. As a result, fishers from the two communities frequently captured fish that were second-degree relatives. In contrast, the probability of social ties among fishers changed significantly depending on the type of connection and was considerably low for leadership and kinship although some communication was present. Our study highlighted how local actions (e.g., recovery from marine reserves or overfishing) are likely to impact the neighboring community as much as locally. The geographic scale and strength of key ecological process supporting fish stocks through the fish life cycle seem to be larger than those of social connections among fishers. Fishers and managers could benefit from a broader regional perspective that strengthens connections between communities about shared goals and activities. We examine some insights learned on the constraints of connectivity given different attributes of each ecological and social component and methodological challenges identified. We also discuss ways to improve collaborative management between the two communities.
\end{abstract}

Key Words: connectivity; Gulf of California; kinship; larval dispersal; networks; small-scale fisheries; social-ecological

\section{INTRODUCTION}

Preserving the multiple services that marine ecosystems provide is one of the main challenges of modern civilization considering the huge extent of the human footprint on aquatic environments (Pauly and Zeller 2016, FAO 2020). Multiple interdisciplinary frameworks have been proposed to match management strategies to the social and ecological contexts of environmental problems to maintain ecosystem structure and function. Some of these frameworks include ecosystem-based management (Pikitch et al. 2004), social-ecological systems (Ostrom 2009), social-ecological alignment or fit (Cumming et al. 2006), collaborative governance (Bodin 2017), among others. Common to these frameworks is the need to understand connections within and between ecological and social elements to improve management outcomes. However, comparing empirical estimates of connectivity across disciplines is not easy (Turnbull et al. 2018). Some of the difficulties include the complexity of natural and social systems, the need of transdisciplinary research tools to assess and compare connectivity, and the obstacles of matching spatial and temporal scales of measurement.

A promising method for conceptualizing social-ecological connections is representing them within a network framework (Janssen et al. 2006, Bodin et al. 2019, Sayles et al. 2019). Networks can be used to show how people interact with a common ecological resource as a link, such as fishing (Bodin and Crona 2009). In this approach, networks are composed of nodes representing the social or ecological components and links representing their connections (Janssen et al. 2006). The social and ecological systems can be symbolized as separate but interconnected network layers in a multilevel network (Barnes et al. 2019, Bodin et al. 2019). Networks have the advantage of being flexible to represent diverse data, including for example the relationships within and between groups of people or organizations (Borgatti et al. 2009), or the export and import of fish larvae between sites driven by ocean currents (Treml et al. 2008). Besides explicitly accounting for the presence, intensity, and direction of connections in a spatial context, networks could reveal interdependence and feedback loops between components, and could be used to identify nodes that play key roles in the structure of the network (Turnbull et al. 2018, Sayles et al. 2019).

Social-ecological alignment or fit is accomplished when relationships between social actors are paired with links in the ecological network (Bodin 2017). Social-ecological alignment is usually associated with one or more indicators of sustainability, and contextual attributes that contribute to success are commonly identified (Epstein et al. 2015). In its simplest form, the problem of social-ecological fit could be exemplified by two sets of actors (e.g., two adjacent local communities of small-scale fisheries),

${ }^{1}$ Conservation Genetics Laboratory and Desert Laboratory on Tumamoc Hill, University of Arizona, Tucson, AZ, USA, ${ }^{2}$ Applied Genomics Lab, La Paz, Baja California Sur, México, ${ }^{3}$ Universidad Autónoma de Baja California - Facultad de Ciencias Marinas, Ensenada, Baja California, México., ${ }^{4}$ Comunidad y Biodiversidad A.C., Guaymas, Sonora, México, ${ }^{5}$ Independent consultant, ${ }^{6}$ The Nature Conservancy, La Paz, Baja California Sur, México, ${ }^{7}$ Instituto Politécnico Nacional - CICIMAR, Bioeconomía Pesquera y Acuícola, La Paz, Baja California Sur, México 
each exploiting an ecological component (e.g., a particular fish species), which populations show strong interdependencies between them driven by the characteristics of the underlying biophysical system (e.g., ocean currents). If the actors that share the ecological component communicate with each other, it can facilitate coordination and cooperation toward sustainable management and increase the health and sustainability of the resource (Bodin 2017). This type of closed network structure could increase trust, learning, sharing of information, and enable establishing rules (Bodin et al. 2016). In contrast, the lack of social connections despite the presence of ecological links reduces the ability to address environmental problems effectively and reduces the likelihood of meeting socioeconomic and ecological longterm goals (e.g., avoid overfishing and associated loss of income due to stock depletion). A mismatch could also appear when the scales of ecological processes do not match the scales of governance structures (Cumming et al. 2006, Cumming and Dobbs 2020). Adaptive co-management of small-scale fisheries that promotes the participation of direct users, governments, and other stakeholders in decision-making processes have recently proliferated (d'Armengol et al. 2018). However, the discussion of principles for efficient governance has continued and is recognized as a key piece to overcome the underlying causes of overexploitation in fisheries (Quentin Grafton et al. 2007, Henry and Dietz 2011, Hilborn et al. 2020).

Small-scale fisheries in the Midriff Island Region (MIR) of the Gulf of California (GC), Mexico, targeting marine fish represent an ideal system to evaluate the challenges of measuring the connections between complex ecological and social systems. Most studies that simultaneously characterize ecological and social connections related to fisheries usually focus on trophic relationships among multiple species targeted by fishers (Yletyinen et al. 2018, Barnes et al. 2019, Kluger et al. 2019), or how fishing vessels interact with multiple fisheries (Fuller et al. 2017). However, ecological connections within any single one of those species are also important (Treml et al. 2015), but difficult to observe empirically and commonly ignored given their hidden nature. Fish populations are connected to each other via movements during different life history stages, including larvae, juvenile, and adult (Munguia-Vega et al. 2018). This type of ecological connectivity has demographic effects on population recruitment and abundance and its maintenance is crucial for the viability of local populations by shaping the metapopulation structure and resilience of a stock (Jones et al. 2009). For many species of marine fish and invertebrates, oceanographic currents mediate patterns of larval dispersal between sites, generally over a larger spatial scale compared to the movement of juveniles and adults within their home range, ontogenetic habitat shifts, or spawning migrations (Green et al. 2015, Munguia-Vega et al. 2018). Fisheries that exhibit spatial complexity where separated populations are linked via larvae and adult dispersal creates serious challenges to traditional fisheries management that assumes control of a single, spatially homogeneous stock via fishing mortality (Wilson 2006, Berger et al. 2017). Specifically, fishing could push a population across a threshold beyond which the successful reproduction is threatened, and ignoring the connections among fish populations could lead to disrupting demographic links, overexploitation, and loss of resilience of the system as a whole (Wilson 2006, Berger et al. 2017).
Fishers connect and interact with each other depending on different types of social ties, including kinship, communication, trust, reciprocity, leadership, co-occurrence of fishers in the same fishing grounds, etc. (Bodin and Crona 2009). Identifying social linkages provides channels (e.g., kinship ties, key players or leaders) for exchanging information (e.g., good fishing areas, permits, subsidies, new technologies, fisheries regulations, stock status) within and between communities in ways that could both support or hinder conservation and management efforts (ZetinaRejón et al. 2020). Stakeholders' relationships shape the structure of social networks, which can impact governance dynamics (Hartley 2010). The term "small-scale fishery" is commonly defined mostly by its technological characteristics (i.e., type of gear and boat length) and fishing regulations tend to focus solely on the action of "fishing" (i.e., regulating fishing access or fishing methods), putting sociocultural and commercial dimensions aside (Smith and Basurto 2019, Basurto et al. 2020). The MIR fisheries are de facto open access (Cinti et al. 2014) and although all fishers should operate under permits there is limited enforcement, particularly outside existing protected areas. Like most small-scale fisheries around the world, MIR fisheries are generally self-governed through informal arrangements under cooperative or non-cooperative structures, which translates to cooperatives versus a patron-client arrangement (Lindkvist et al. 2017). To gain fishing access, fishers either work for patrons or as part of cooperatives, with both typically commercializing their catches through intermediaries (Cinti et al. 2014, Basurto et al. 2020). Although fishers are most incentivized to join cooperatives when they live in communities with high transaction costs for selling and commercializing their catch, governance arrangements seem to develop depending on their social-ecological fit, and potential for adaptation to variability (Basurto et al. 2013a).

Our study focused on fishers targeting leopard groupers (Mycteroperca rosacea). The species shows a complex life history including spawning aggregations, a 28 -days pelagic larval stage after which juveniles travel to Sargassum spp. forests and later relocate to rocky reefs as adults (Munguia-Vega et al. 2014). Leopard grouper is the most heavily targeted grouper by smallscale and recreational fisheries in the GC (Sala et al. 2003, Erisman et al. 2010), and its population status is considered to be decreasing (Erisman and Craig 2018). Leopard grouper annual landings averaged 147 tons in the GC between 1999 and 2007 (Erisman et al. 2010). The species is exploited via hand lines or spearguns with support from surface-supplied air (hookah diving; Moreno-Báez et al. 2012). This small-scale fishery operates from small skiffs (7 m long), known locally as "pangas," that are powered by outboard motors and manned by two to three fishers. The leopard grouper is part of the finfish fishery, which is managed via commercial permits that include more than 200 species exploited in Mexico, with no specific regulations regarding gear, catch, or size restrictions. No-take zones (fully protected marine reserves, fish refuges, etc.) represent the main spatial management tool implemented for leopard groupers and other finfish species in the MIR (Rife et al. 2013). Current efforts are underway to scale up the establishment of new marine reserve networks in the GC (Alvarez-Romero et al. 2018, Morzaria-Luna et al. 2020).

A first step toward evaluating the fit between social and ecological components in an environmental problem generally proceeds by 
characterizing the attributes of the ecological system and then comparing these to the attributes of governing institutions (Epstein et al. 2015). To this end and to help facilitate stakeholder engagement and co-management, this study aimed to use a multilevel social-ecological network as a framework to conceptualize and analyze the ecological and social connectivity between two adjacent communities of small-scale fishers targeting the same fish species. We were interested in estimating the level of interconnectedness between populations of leopard grouper targeted by each community and measuring the level of social connections present among fishers. Our specific objectives were (1) estimate the extent of overlap in the cohorts of fish caught and fishing sites used by each community, (2) measure the presence and strength of larval and adult dispersal in fish captured within and between the fishing grounds from each community, (3) quantify the presence and level of social connections within and between fishers from each community. We identified some characteristics of these ecological and social systems that promote or inhibit connectivity and discuss how the specific biophysical characteristics of the ecological system constrain the way collaborative arrangements should ideally be devised. Our main assumption was that, if strong ecological links are present between the two communities, then management decisions that improve (e.g., marine reserves) or reduce (e.g., overfishing) the size of the shared fish stock will have impacts on the adjacent community, and thus improving communication and comanagement between the two communities could help toward sustainably managing the fishery.

\section{METHODS}

\section{Study area}

The northern GC, which includes the MIR, has 45 islands and islets, and is a globally recognized marine biodiversity hot-spot (Alvarez-Romero et al. 2013). The northern GC region is of key importance for 17 communities of small-scale fishers, where nearly 80 fish and invertebrate species are targeted by $>3500$ fishers using $>1600$ pangas (Munguia-Vega et al. 2015). We focused our study on Puerto Libertad (PL) and Bahia Kino (BK), two communities located in the state of Sonora on the eastern shore of the GC (Fig. 1). PL is an isolated community of $\sim 2800$ inhabitants. Small-scale fishing is the main economic activity of 200 local fishers with 119 pangas, focused on migratory species such as sharks, croakers, sierra, and yellowtail among others, along with coastal species including groupers and snappers (Espinosa-Romero et al. 2014). BK ( 6000 inhabitants) is a larger and more economically diverse community, with at least 460 local fishers and 365 pangas according to a Spatial Fisheries Planning Program conducted in 2013 (Fernandez-Rivera Melo et al. 2018). Considering the ratio between the number of fishers and pangas (Johnson et al. 2017) and that there are two or three fishers per panga, the fisher population of both BK and PL is likely double or triple the reported number. BK is closest to the state capital and has access to better infrastructure than PL, including major roads in better condition that provide access to more varied market possibilities, fishing equipment, gear and supplies stores, etc. BK is also an important tourist destination (e.g., 25,000 tourists during spring break 2019).
Fig. 1. Fishing zones for leopard groupers (Mycteroperca rosacea) captured by fishers from Bahia Kino (circles) and Puerto Libertad (triangles) in the Gulf of California, Mexico. Fishing sites from each fisher within each community are distinguished by different colors. Lines in the background show polygons used to define eight distinct fishing zones from BK and three fishing zones from PL. The location of no-take marine reserves is indicated by asterisks $(*)$.

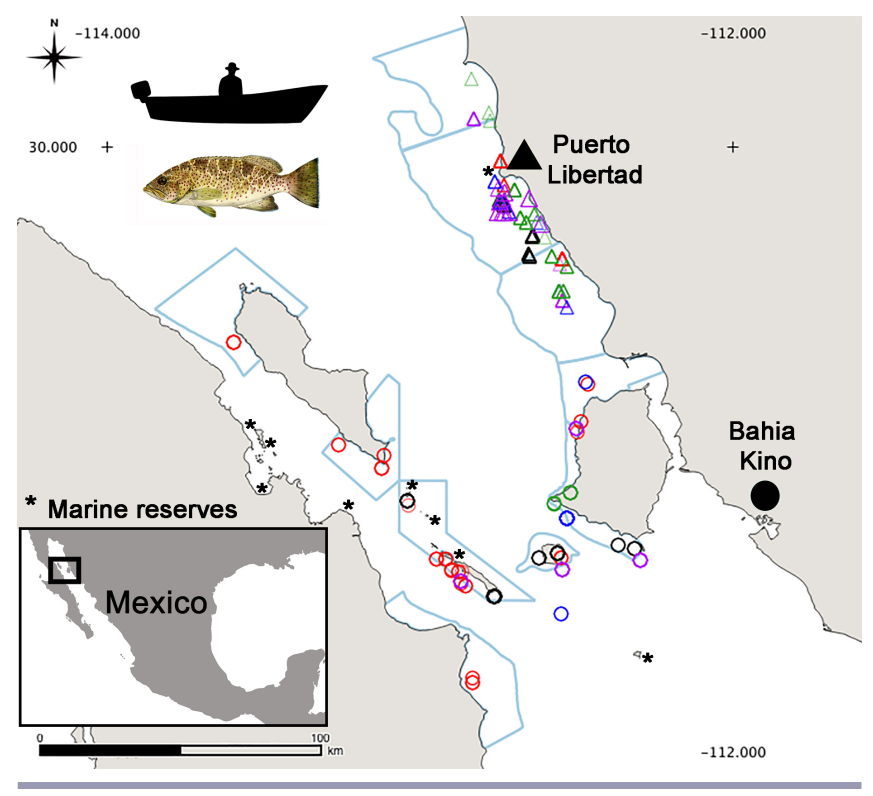

Formalized fishing in this part of the MIR dates back to 1935, progressively increasing until the 1980s/1990s when the fishing activity became increasingly intensive and extensive (Frawley et al. 2019a). However, over the years, other economic activities have emerged in the community, including trade, cottage industries, crafts, tourism, and even livestock and family gardens (Moreno et al. 2005). Fishing for leopard groupers occurs during spring and summer in each community using different gear. In BK leopard groupers are caught with spearguns and hookah diving, whereas in PL the species is targeted with hand lines. Leopard grouper along with other fish (corvina, sierra, gulf coney) are the most important species in terms of economic value in PL. In BK, though the species is not the most important economically, it is found among 24 species recognized as important for its economic value or catch volume (Fernandez-Rivera Melo et al. 2018).

\section{Fish sampling}

To obtain information about the use of fishing zones and the level of ecological connectivity between the fish captured by each community, in June 2016 we established a citizen science program with five fishers from each of the two communities that target leopard groupers. Sampling focused on obtaining information about fishing sites, tissue samples of fish for genetic analyses of kinship to estimate ecological connectivity, and size of the fish to approximate its age and distinguish parent-offspring from fullsib relationships. Fishers were provided with a sampling kit that included a global positioning system(GPS) to record the sampling location of each captured fish, a ruler to measure the total length 
of each organism, $1.5 \mathrm{ml}$ pre-labeled screw-cap vials, ethanol, dissection scissors to collect fin clips as a source of DNA, and a water-resistant paper format to register the corresponding information. Fishers kept the contents of the sampling kit at the end of the study as an incentive for participating in the study.

To estimate the geographical extent and overlap among fishing zones within and between communities we built a geographic information system (GIS). We used the GPS coordinates of the sampling location of each individual leopard grouper collected from each fisher. We identified 11 fishing zones used by fishers of both communities based on a previously described delimitation of fishing zones of leopard grouper for the MIR (Munguia-Vega et al. 2014; Fig. 1). Fishing zones were defined by the $100 \mathrm{~m}$ isobath, inside which most small-scale fishing takes place, and also incorporated natural geographic features (islands) and existing marine protected areas.

\section{Ecological data}

To obtain empirical estimates of ecological connectivity for leopard groupers, we conducted genetic analyses with the tissue samples collected by the fishers from each community. We extracted genomic DNA from fin clips using the DNeasy Blood and Tissue Kit (QIAGEN) or with the salting-out method (Aljanabi and Martinez 1997). We genotyped 13 microsatellite loci on each sample, including five loci (Mros03, Mros05, Mros07, Mros11, and Mros12) previously described (Jackson et al. 2014). We also analyzed eight new markers isolated during the genomic sequencing run described in Jackson et al. (2014) that were genotyped using the same PCR conditions and methods referenced above (Appendix 1, Table A1.1), including loci Mros 17, Mros18, Mros22, Mros25, Mros26, Mros27, Mros29, and Mros32. We estimated deviations from Hardy-Weinberg equilibrium (HWE) and linkage disequilibrium (LD) for each combination of loci and populations using GENEPOP 4.2 with 10,000 dememorization steps, 1000 batches and 10,000 iterations (Raymond and Rousset 1995).

Based on the data collected about total fish length, we categorized individuals into age classes for the analysis of genetic kinship following intervals obtained from a previous study of age-length relationships in leopard grouper (Diaz-Uribe et al. 2001). We assigned individuals into two groups based on their age: (1) candidate parents (older individuals with total length ranging from 52 to $90 \mathrm{~cm}$ corresponding to $>7$ to $12+$ years old); and (2) candidate progeny (younger individuals with total length ranging from 20 to $43 \mathrm{~cm}$ corresponding to $>1<5$ years old). These two groups were separated by an age gap equal to the time for reproductive maturity, which is estimated at two years (DiazUribe et al. 2001).

We used the genetic data to estimate two measures of ecological connectivity. First, we measured kinship identifying pairs of individual fish with a probability $\geq 99.0 \%$ of being first-degree relatives (e.g., parent-offspring, full sibs) or second-degree relatives (grandparent-grandchildren, half-sibs, avuncular: uncle, aunt, nephews, nieces) using the COLONY software (Jones and Wang 2010). We assumed a polygamous mating system for a diploid and dioecious species, a mutation rate for a microsatellite locus of 0.0005 , and four long runs to estimate likelihood. Second, we detected first-generation migrants among the 11 fishing zones from the two communities using a Bayesian assignment method
(Rannala and Mountain 1997) implemented in GENECLASS2 (Piry et al. 2004). For each individual fish, we assessed the likelihood ratio L-home/L-max using Monte Carlo resampling and simulating 10,000 individuals. Those individuals with a probability $\leq 0.01$ of belonging to the population where they were sampled were identified as migrants. We constructed an asymmetric matrix among the fishing zones that represented the presence and frequency of the inferred migration events.

We estimated a third measure of ecological connectivity, namely, larval connectivity of leopard groupers driven by oceanic currents. We used the raw output of a previous study to estimate a directed larval connectivity network representing the probability of larval dispersal among the relevant fishing zones identified from the MIR (Munguia-Vega et al. 2014). Dispersal was estimated on the basis of a three-dimensional HAMSOM oceanographic model that simulated the oceanic currents during the spawning season (May and June) for a planktonic larval duration of 28 days and which accuracy was previously validated with genetic data (Munguia-Vega et al. 2014).

\section{Social data}

To identify the presence and level of social connectivity within and between fishers from BK and PL targeting leopard grouper, we used a non-probabilistic sampling based on a realistic approach (Zepeda-Dominguez et al. 2017). The realistic approach consisted of a structured interview, composed of open and closed questions, applied to 83 fishers ( 49 from BK and 34 from PL) that targeted leopard grouper and who represented all the different groups of interest (cooperatives, permit holders and free fishers) present within each locality (Zepeda-Dominguez et al. 2015). The number of fishers interviewed represent $10.6 \%(\mathrm{BK})$ and $17 \%$ (PL) based on the latest available estimates of the number of fishers targeting all species in each community. The survey sought to identify the main leopard grouper fishers of the MIR and the existing social relationships within and between the two communities. We identified five variables of interest to measure social connectivity, specifically communication, trust, reciprocity, leadership, and kinship (Bodin and Crona 2009). Communication refers to the existence of any information exchange between fishers. We considered trust as the intention to accept vulnerability based upon positive expectations of the intentions of the behavior of another person (Ostrom and Walker 2003). Reciprocity was understood as the conditional behavior depending on the perceived intentions behind the actions of others (Cox 2004). Leadership was defined as the capability of an actor to exert influence over the other fisher's decisions. These variables were ranked from bad to excellent on a numerical scale ( 1 being bad and 5 was excellent; see Appendix 2, Table A2.1 for details). The fishers identified in this interview were then used in a second interview to identify kinship among fishers (first- and seconddegree relatives, as defined above). For the design, validation, and application, regular protocols for social research were observed: every fisher was informed about the project, including the goals, the methodology, the anonymity of the data, and the policy of not sharing any information for purposes different from those consented. We also provided channels to express any concern or refusal to include their information and a way to contact a technical person responsible for the project (Fontana and Frey 2005). With the data obtained for the five variables describing social interactions, we generated five adjacency matrices (kinship, 
communication, trust, reciprocity, and leadership). Matrices represented binary data for the presence or absence of a social relationship between two fishers.

\section{Contrasting ecological and social networks}

Network analyses use graph theory to study the topological and functional relationships of nodes (Newman 2003), which in our study were represented by fish, fishing sites, and fishers, as a tool to understand the dynamics of social-ecological systems (Sayles et al. 2019). Social network analysis has been used successfully for the structural characterization of natural resource management systems (Prell et al. 2008). Two actors who share a social bond over time will influence each other, tending to increase the similarity between the two. If, in addition, this link is deep or multiple (they are friends, coworkers, close relatives), the probability of similarity will increase (Prell 2012). In the context of fisheries management, social network analysis has been used to associate structural attributes with management characteristics and their performance (Bodin and Crona 2008, Hartley 2010).

The matrices describing three ecological relationships and five social ties were analyzed and visualized using a graphic network approach with the software GEPHI (Bastian et al. 2009). In ecological networks, the nodes of the kinship network were represented by individual fish analyzed, whereas for the fish migrants and the probability of larval dispersal nodes were represented by the fishing zones used by each community and links defined by the presence/absence and intensity of ecological connectivity among them. In social networks, nodes represent individual fishers connected by the five types of social ties. To analyze the role of each node in the network structure, we used the eigen centrality index to measure the importance of each node as its positional relevance (Wasserman and Faust 1994). Eigen centrality is a measure of a node's influence on a network. For its calculation, relative scores are assigned to all the nodes in the network; a node will have a high score if it is connected to highly connected nodes, and conversely it will have a low score if it is connected to poorly connected nodes. This means that the ownvector centrality is proportional to the sum of the centralities of the nodes with which it is connected (Bonacich and Lloyd 2001).

To compare the level of connectivity within and between the two fishing communities in each ecological and social network, we estimated the density from the three ecological and five social networks. For each network, we defined density as the number of links observed divided by the maximum number of possible links (Janssen et al. 2006), while ignoring the diagonal of the matrix. Density represents the probability that any given tie between two random nodes is present (Hanneman and Riddle 2005). A network has a maximum density of 1 if all possible links among all nodes are present and a minimum density of 0 if no links are present. Estimates of density can be used to compare the level of cohesiveness or saturation among different networks and are related to some functional attributes like the level of resilience of the network (Janssen et al. 2006). All the networks were treated as directed networks. In each network, we calculated density considering links as a binary variable (i.e., present or absent) in four sub-networks to decompose the probabilities of finding a link within compared to between the two communities: (1) a subnetwork labeled $B K$ including links only between nodes belonging to Bahia Kino; (2) a subnetwork labeled $P L$ including links only between nodes from Puerto Libertad; (3) a network labeled All including all the nodes and links; and (4) a subnetwork labeled $B K-P L$ excluding the links within each community and considering only the potential ties exclusively between two nodes from different communities. We evaluated statistical differences in the observed densities of networks and subnetworks by computing the sampling variance of the estimated densities by using bootstrapping and the "Compare Densities" function in UCINET 6.718 (Borgatti et al. 2002). This method is analogous to the classical paired sample t-test for estimating the standard error of the difference. We generated a sampling distribution of density measures in 10,000 random sub-samples to account for the interdependency of network data.

\section{RESULTS}

\section{Fishing patterns}

Our citizen science program with 10 fishers allowed us to collect tissue samples, total length, and geographic coordinates from 776 leopard grouper individuals. Eight fishing zones for BK and three for PL were identified, and fishing zones used by each community did not show any overlap (Fig. 1). Fishers from BK used all the islands in the Midriff Island Region (MIR), and some individual fishers traveled up to $200 \mathrm{~km}$ from their community to their fishing sites. Fishers from PL exclusively fished at sites near their community and within a $50 \mathrm{~km}$ radius. In both communities, fishers shared between one and three fishing zones with other fishers from their community.

Each fishing community targeted fish from different cohorts that varied considerably in size. Fishers from BK captured fish that were significantly smaller (average length $45.06 \mathrm{~cm}, \mathrm{~N}=379$ ) than those captured by fishers from PL (average length $64.20 \mathrm{~cm}, \mathrm{~N}=$ 397, Fig. 2). These fish sizes corresponded to a mean age of five years for fish from BK and nine years for PL.

Fig. 2. Histogram showing the frequency distribution of total length and inferred age of 776 leopard grouper (Mycteroperca rosacea) individuals captured by fishers from Bahia Kino (red) and Puerto Libertad (blue).

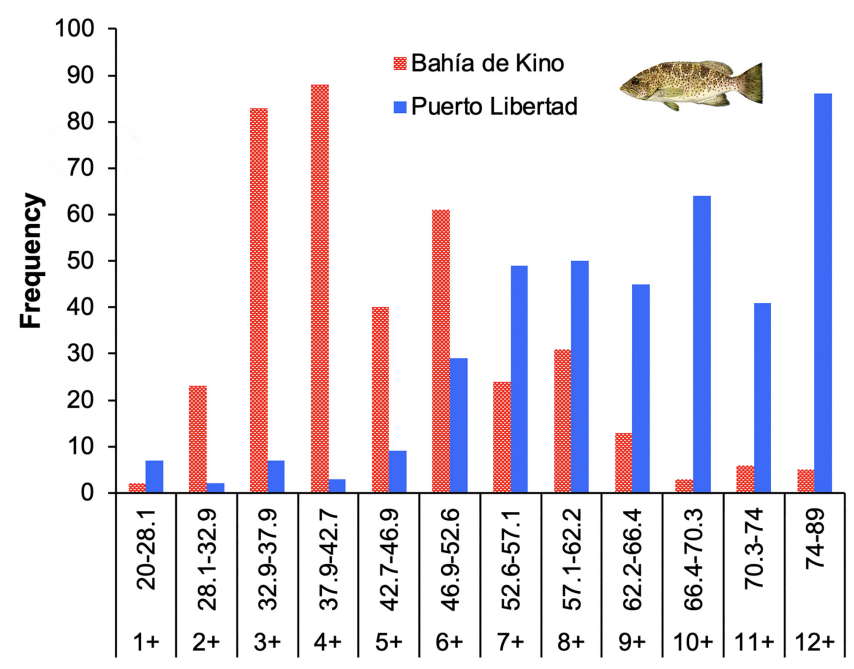

Total length intervals $(\mathrm{cm})$ and age (years) 
Table 1. Characteristics of three ecological (kinship, larvae, migrants) and five social (kinship, communication, trust, reciprocity, leadership) networks within and between two communities of small-scale fishers. We show the number of elements or nodes in the network $(\mathrm{N})$, the maximum number of possible links, observed number of links, the average density of the network, and standard deviation (SD). We show data decomposed into four sub-networks: (1) a subnetwork labeled BK, including links only between nodes belonging to Bahia Kino; (2) a subnetwork labeled PL, including links only between nodes from Puerto Libertad; (3) a subnetwork labeled All, including all the nodes and links; and (4) a subnetwork labeled BK-PL, excluding the links within each community and considering only the potential ties exclusively between two nodes from different communities. Density represents the probability that any given tie between two random nodes is present.

\begin{tabular}{|c|c|c|c|c|c|}
\hline \multicolumn{4}{|c|}{ Ecological Networks of fish and fishing zones } & \multirow[b]{2}{*}{ Density } & \multirow[b]{2}{*}{ SD } \\
\hline & $\mathrm{N}$ & Maximum links & Observed links & & \\
\hline \multicolumn{6}{|l|}{ Kinship } \\
\hline $\mathrm{BK}$ & 138 & 18906 & 79 & 0.0042 & 0.065 \\
\hline PL & 144 & 20592 & 111 & 0.0054 & 0.073 \\
\hline All & 282 & 79242 & 355 & 0.0045 & 0.067 \\
\hline BK-PL & & 39744 & 165 & 0.0042 & \\
\hline \multicolumn{6}{|l|}{ Larvae } \\
\hline BK & 8 & 56 & 34 & 0.6071 & 0.488 \\
\hline PL & 3 & 6 & 3 & 0.5000 & 0.5 \\
\hline All & 11 & 110 & 50 & 0.4545 & 0.498 \\
\hline BK-PL & & 48 & 13 & 0.2708 & \\
\hline \multicolumn{6}{|l|}{ Migrants } \\
\hline $\mathrm{BK}$ & 8 & 56 & 11 & 0.1964 & 0.397 \\
\hline PL & 3 & 6 & 3 & 0.5000 & 0.5 \\
\hline All & 11 & 110 & 29 & 0.2636 & 0.441 \\
\hline BK-PL & & 48 & 15 & 0.3125 & \\
\hline \multicolumn{6}{|c|}{ Social Networks of fishers } \\
\hline $\mathrm{BK}$ & 49 & 2352 & 30 & 0.0128 & 0.112 \\
\hline PL & 34 & 1122 & 51 & 0.0455 & 0.208 \\
\hline All & 83 & 6806 & 83 & 0.0122 & 0.11 \\
\hline BK-PL & & 3332 & 2 & 0.0006 & \\
\hline \multicolumn{6}{|c|}{ Communication } \\
\hline BK & 49 & 2352 & 8 & 0.0034 & 0.058 \\
\hline PL & 34 & 1122 & 97 & 0.0865 & 0.281 \\
\hline All & 83 & 6806 & 235 & 0.0345 & 0.183 \\
\hline BK-PL & & 3332 & 130 & 0.0390 & \\
\hline \multicolumn{6}{|l|}{ Trust } \\
\hline BK & 49 & 2352 & 9 & 0.0038 & 0.062 \\
\hline PL & 34 & 1122 & 101 & 0.0900 & 0.286 \\
\hline All & 83 & 6806 & 250 & 0.0367 & 0.188 \\
\hline BK-PL & & 3332 & 140 & 0.0420 & \\
\hline \multicolumn{6}{|c|}{ Reciprocity } \\
\hline BK & 49 & 2352 & 9 & 0.0038 & 0.062 \\
\hline PL & 34 & 1122 & 102 & 0.0909 & 0.287 \\
\hline All & 83 & 6806 & 250 & 0.0367 & 0.188 \\
\hline BK-PL & & 3332 & 139 & 0.0417 & \\
\hline \multicolumn{6}{|c|}{ Leadership } \\
\hline BK & 49 & 2352 & 127 & 0.0540 & 0.226 \\
\hline PL & 34 & 1122 & 94 & 0.0838 & 0.277 \\
\hline All & 83 & 6806 & 253 & 0.0372 & 0.189 \\
\hline BK-PL & & 3332 & 32 & 0.0096 & \\
\hline
\end{tabular}

\section{Ecological networks}

Fish Kinship

Our first measure of ecological connectivity was based on genetic kinship analyses of 282 fish that passed strict quality controls (Appendices 3-6), from which 138 fish were from BK and 144 fish were from PL. We found 355 first- and second-degree relationships among the genotyped fish, of which $111(31.26 \%)$ were from fish captured within PL fishing grounds, 79 (22.25\%) were from fish captured within BK fishing grounds, and the majority $(165,46.47 \%)$ were between pairs of fish captured in the fishing zones of two distinct communities (Table 1, Fig. 3a). From all relationships, only $4.78 \%$ (17) were between first-degree relatives. All first-degree relationships were found within the fishing zones of PL, including three parent-offspring and 14 fullsibling pairs. According to the analyses of eigenvector centrality, most of the important nodes in the network of genetic relationships were fish from PL (Fig. 3). The probability of observing a kinship link within two random fish (i.e., density) in the subnetworks within and between communities was small (< $1 \%$ ) and within the same order of magnitude. Despite density 
Fig. 3. Networks describing kinship (first- and second-degree relationships) among 282 leopard groupers, Mycteroperca rosacea, (a) and 83 fishers (b) from two communities. Nodes represent individual fish and fishers, colored according to the community to which they belong $($ Red = Bahia Kino, BK; blue = Puerto Libertad, PL $)$. Node size represents the eigenvector centrality. The links show first-degree (thick lines) or second-degree relationships (thin lines). Links within BK are shown in red, links within PL are shown in blue, and green links represent relationships between nodes from different communities.
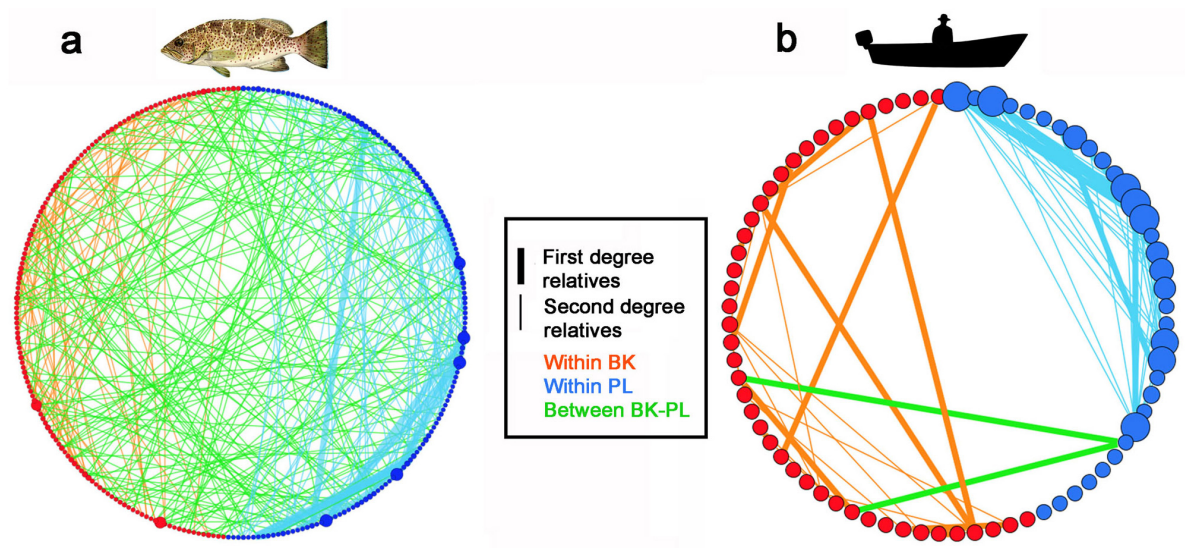

being slightly lower within BK $(0.41 \%)$, we did not observe any significant difference compared to PL $(0.53 \%)$, neither with the network including all fish $(0.44 \%)$ or with the comparison focused between the two communities $(0.41 \%$; Fig. 4 , all $\mathrm{P}$ values $>0.058$, Appendix 7, Table A7.1).

\section{Fish migrants}

Our second measure of ecological connectivity based on the identification of first-generation fish migrants revealed 60 of the 282 fish as migrants $(21.27 \%)$ whose genotypes were more likely to have originated in a different fishing zone from where they were captured (Fig. 5a, Table 1). Strong connections were observed in a southward direction indicating the migration of individuals from the central fishing zones of PL toward the fishing zones of $\mathrm{BK}$ in the MIR. The 60 migrants were distributed into 29 links, from which $11(37.93 \%)$ were between BK fishing zones, 3 $(10.34 \%)$ were between PL fishing zones and the bulk $(15,51.72 \%)$ were between fishing zones from two different communities. We observed the highest density in the subnetwork of migrants among PL fishing zones (50\%), which was significantly higher than the value observed among BK fishing zones $(19.64 \%, \mathrm{P}=$ 0.001), larger than the density of the network including all fishing zones $(26.36 \%, \mathrm{P}=0.001)$ and higher than the comparison between the fishing zones of the two communities $(31.25 \%, \mathrm{P}=$ 0.025, Fig. 4, Appendix 7, Table A7.1).

\section{Larval dispersal}

Our third measure of ecological connectivity based on an oceanographic model of larval dispersal for leopard grouper (Munguia-Vega et al. 2014) showed 50 larval dispersal links, from which the majority $(34,68 \%)$ were between BK fishing grounds, followed by 13 links $(26 \%)$ between different communities showing strong northward connections from the fishing zones of BK toward fishing zones from PL (Fig. 5b, Table 1). Only 3 links $(6 \%)$ were observed between PL fishing zones. The density of subnetworks varied from $60.71 \%$ within BK fishing zones, to $50 \%$ within PL, and $45.45 \%$ overall, which were significantly higher than the density observed between the two communities $(27.08 \%$, all $\mathrm{P}$ values $\leq$ 0.031, Table 1, Fig. 4, Appendix 7, Table A7.1).
Fig. 4. Probability that any given tie between two random nodes is present (density) within the ecological and social networks and subnetworks. Ecological networks (a) include larval dispersal of leopard grouper (Mycteroperca rosacea) among fishing zones, kinship among individual fish, and migrant fish among fishing zones. Social networks (b) include kinship, communication, and leadership among individual fishers. Subnetworks include links between nodes from BK (BK), links between nodes from PL (PL), all nodes and links (All), exclusively links between two nodes from different communities, ignoring links between nodes from the same community (BK-PL). See Appendix 7 for statistical analyses.

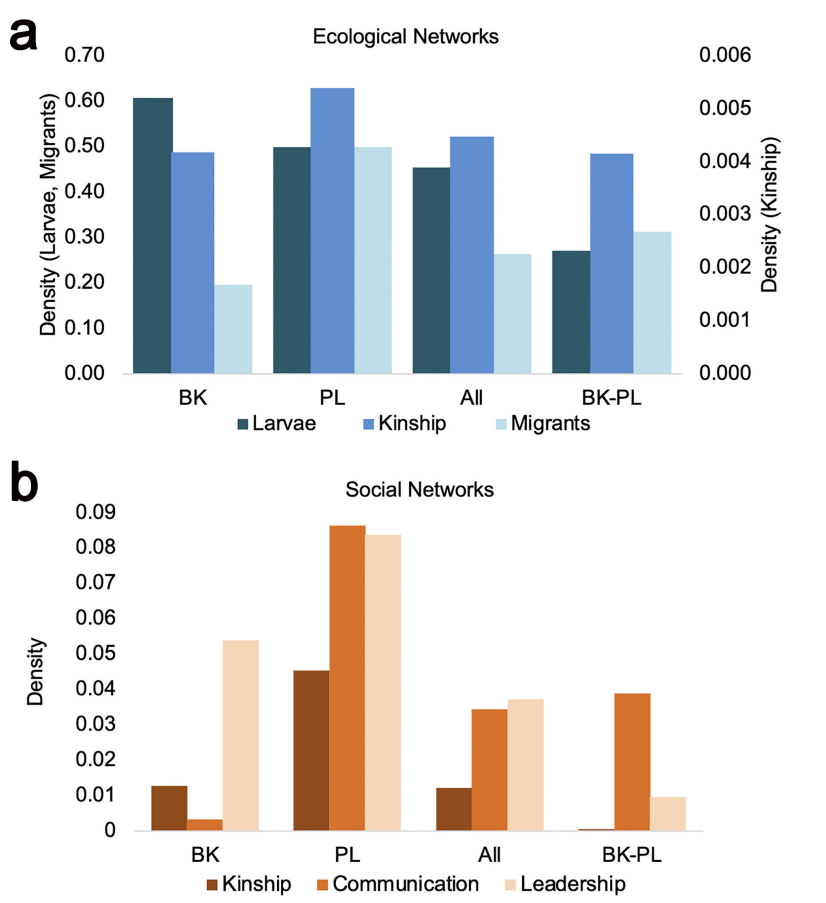


Fig. 5. Ecological networks between fishing zones from two communities in the northern Gulf of California. (a) Network showing 60 first-generation migrants that integrate larval, juvenile, and adult dispersal identified via genetic analyses among eight fishing zones from Bahia Kino (BK, gray polygons) and three fishing zones from Puerto Libertad (PL, white polygons). (b) Network showing the probability of larval dispersal among fishing zones from the two communities, based on a three-dimensional oceanographic model. Links within BK are shown in red, links within PL are shown in blue, and green links represent relationships between the two communities. Line width is proportional to the observed frequency, and the thickest lines represent the maximum values: seven migrant individuals in (a), and $27.6 \%$ probability of larval dispersal in (b).

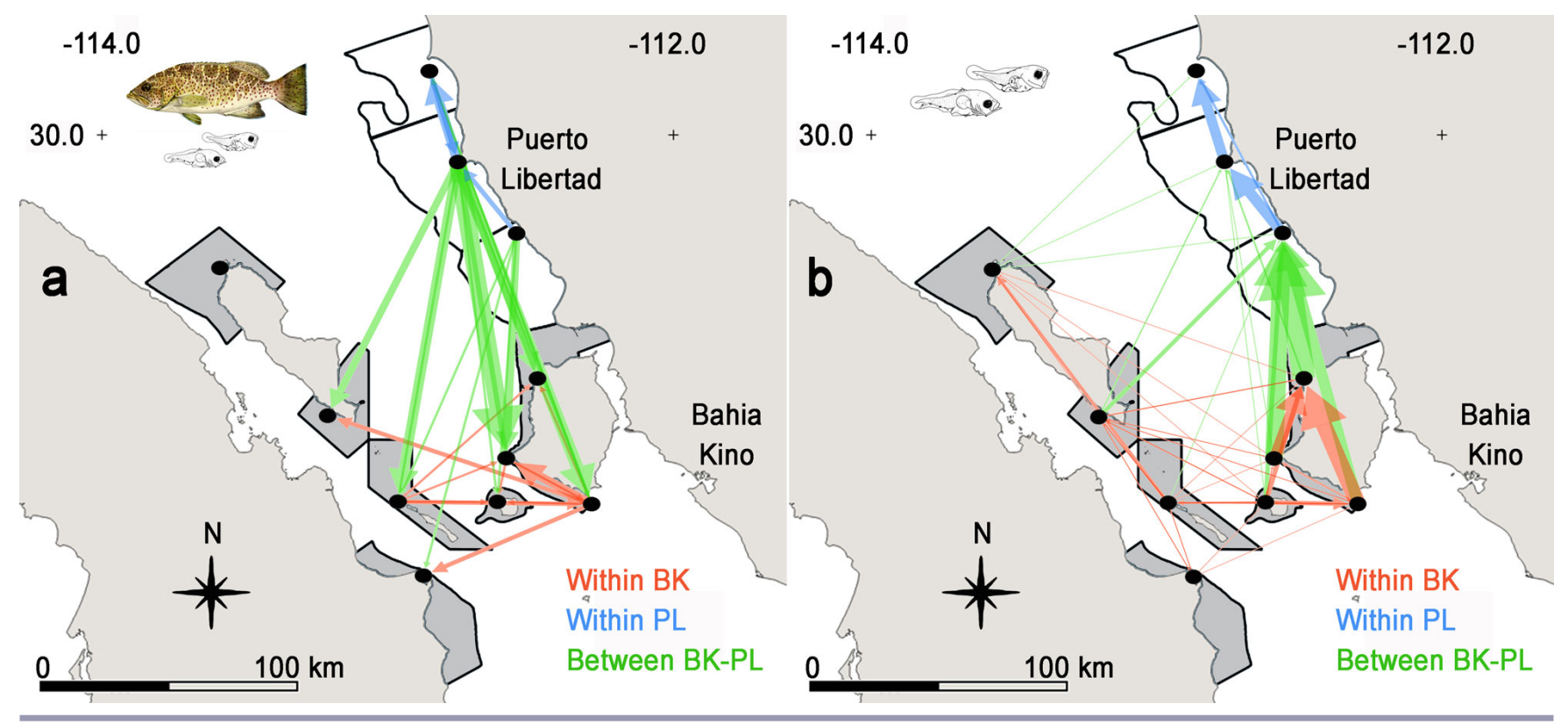

\section{Social networks}

\section{Fishers' kinship}

From 83 fishers that were interviewed for the analyses of kinship (49 from BK and 34 from PL), our first measure of social connectivity based on kinship among fishers identified 83 connections, from which most $(51,61.44 \%)$ were among PL fishers, compared to 30 links among BK fishers $(36.14 \%)$, while there were only 2 connections $(2.4 \%)$ between the two communities (Table 1, Fig. 3b). From all observed relationships, $26(31.32 \%)$ were between first-degree relatives: 13 within BK, 11 within PL, and only two between the two communities. Analysis of eigenvector centrality showed that all of the most important nodes were fishers from PL (Fig. 3b). The density of the subnetwork of kinship among fishers was significantly higher within PL (4.54\%) compared to within BK (1.27\%, P = 0.001), also higher than the overall network $(1.21 \%, \mathrm{P}=0.042)$ and larger compared to the comparison between links from the two communities $(0.06 \%, \mathrm{P}=0.015$, Fig. 4 , Appendix 7, Table A7.1).

\section{Communication, trust, and reciprocity}

Our second, third, and fourth measures of social connectivity among fishers (communication, trust, and reciprocity) showed almost identical results among them. Social connections were more frequent within fishers from PL compared to BK, and there was a significant number of social connections between the two communities (Fig. 6a, Appendix 8, Fig. A8.1). We identified 235 communication links overall, from which $97(41.27 \%)$ were among PL fishers, $130(55.31 \%)$ were between fishers from distinct communities, and only $8(3.40 \%)$ were among BK fishers. The density of the subnetworks for communication was consistently higher within PL (8.64\%), and an order of magnitude lower within BK (Fig 6a, 0.34\%, P = 0.001, Fig. 4, Appendix 7, Table A7.1). Comparatively, the density of the overall network and the comparison between communities showed intermediate values $(3.45 \%$ and $3.90 \%)$ that were significantly different from the values observed within communities (All P values $\leq 0.023$ ). Relationships between communities for these three variables were symmetrical because communication, trust, and reciprocity were frequently observed from BK fishers toward PL fishers and vice versa. The networks contained a few isolated nodes, suggesting that some of the interviewed fishers did not communicate, trust, or have reciprocal relationships with others.

\section{Leadership}

Our fifth measure of social connectivity (leadership) showed similar levels of social connections within fishers from BK compared to PL, but a much lower frequency of social ties between the two communities (Fig. 6b). From 253 leadership ties identified, $127(50.19 \%)$ were among BK fishers, $94(37.15 \%)$ were among PL fishers, and only $32(12.64 \%$ ) were between fishers from the two communities. The density of the subnetwork for leadership was significantly higher within PL (8.37\%) compared to within $\mathrm{BK}(5.39 \%, \mathrm{P}=0.005)$, the overall network $(3.71 \%, \mathrm{P}$ $=0.023)$ and the comparison between the two communities $(0.96 \%, P=0.001$, Fig. 4, Appendix 7, Table A7.1). Notably, leadership relationships between communities were present but were completely asymmetrical. According to BK fishers, $15 \%$ of 
Fig. 6. Networks describing social connectivity among 83 fishers from two communities in the northern Gulf of California: (a) Communication, (b) Leadership. Nodes represent individual fishers colored according to the community to which they belong (Red = Bahia Kino, BK; blue $=$ Puerto Libertad, PL). Node size represents the eigenvector centrality. Links within BK are shown in red, links within PL are shown in blue, and green links represent relationships between two fishers from different communities.

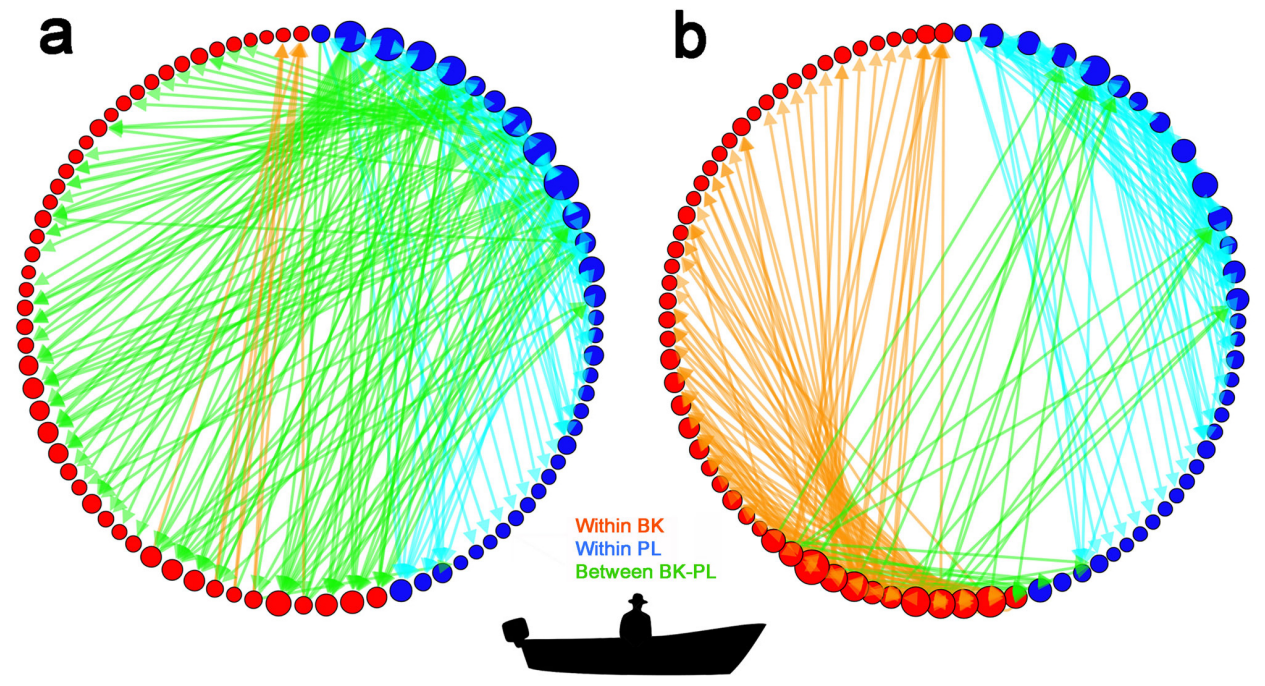

the individuals identified as leaders were from PL, while the rest were fishers from BK (Fig. 6b). In contrast, fishers from PL did not recognize any leaders within $\mathrm{BK}$.

\section{Comparisons within ecological and social networks}

\section{Comparisons within $B K$}

According to our statistical analyses, the probability of finding an ecological link within BK fishing grounds was significantly higher for larvae $(60.71 \%)$ compared to fish migrants $(19.64 \%$, P $=0.001)$, and higher for fish migrants compared to fish kinship ties $(0.41 \%, \mathrm{P}=0.001)$. In terms of social networks, we found a significantly higher probability of finding leadership ties $(5.39 \%)$ compared to kinship ties $(1.27 \%, \mathrm{P}=0.001)$, and a higher probability of kinship ties compared to communication ties (0.34\%, P = 0.025, Fig. 4, Appendix 7, Table A7.2).

\section{Comparisons within PL}

We found that the probability of finding an ecological link within PL fishing zones was identical for larvae and fish migrants $(50 \%)$, and both were significantly higher than the probability of finding fish kinship ties $(0.53 \%, \mathrm{P}=0.001)$. The probability of finding any social tie among fishers within PL was not statistically different for any social measure tested (all $\mathrm{P}$ values $\geq 0.506$, Fig. 4, Appendix 7, Table A7.2) including kinship among fishers (4.54\%), communication (8.64\%), and leadership (8.37\%).

Comparisons between $B K$ and $P L$

When considering the entire ecological network, the probability of finding an ecological link between any fishing zone included in the analyses was not statistically different for larvae $(45.45 \%)$ compared to fish migrants $(26.36 \%, \mathrm{P}=0.063)$, but these two were significantly more likely than finding fish kinship ties $(0.44 \%, \mathrm{P}$ $=0.001)$. When the ecological links within each community were excluded and we focused on the potential ties exclusively between communities, the probabilities observed were also similar for larvae $(27.08 \%)$ and fish migrants $(31.25 \%)$, that were more likely than finding a fish kinship tie $(0.41 \%$, Fig. 4 , Appendix 7 , Table A7.2).

In the social network considering all fishers and all links, it was similarly likely to find a social tie in terms of leadership $(3.71 \%)$ or communication $(3.45 \%, \mathrm{P}=0.334)$, and both were more likely than finding kinship ties $(1.21 \%, \mathrm{P} \leq 0.007)$. However, when the social links within each community were excluded and we focused on the potential ties exclusively between communities, it was much more likely to find a communication tie $(3.9 \%)$ compared to leadership $(0.96 \%)$ or kinship $(0.06 \%)$.

\section{Contrast between ecological and social networks}

A diagram showing a multilevel social-ecological network, including all the ecological and social components analyzed and focused on the connections between the two communities highlights at least two types of social-ecological links present in our study system (Fig. 7). The first set (social-ecological links 1) was represented by the use of fishing sites by fishers. Although fishers from each community do not show any overlap in the use of fishing zones, their fishing zones themselves show multiple ecological links based on larval dispersal and fish migrants. The second set of social-ecological links was represented by the fish caught by fishers, showing that it is common to find kinship ties between any two leopard groupers caught by fishers from distinct communities. Importantly, some social ties, for example, based on kinship among fishers, were sometimes nearly absent between the two communities. In two of our ecological variables (larval dispersal and fish migrants between fishing sites) the likelihood of finding an ecological tie was always significantly higher than finding a social tie, both within and between the two communities of fishers (Fig. 4, Appendix 7, Table A7.3). Although there were differences between the probability of finding an ecological versus a social connection, comparisons between networks of different size are a methodological challenge. 
Fig. 7. Small-scale fishery targeting leopard grouper (Mycteroperca rosacea) in the northern Gulf of California, Mexico, as a multilevel social-ecological network. From top to bottom, Ecological Networks 1 and 2 show larval dispersal (blue links) and fish migrants (green links), respectively, identified among 11 fishing sites (nodes, see map to the right). Social Network shows first and second-degree relationships (red links) among 83 individual fishers represented by nodes. Ecological Network 3 displays kinship (teal links) among 282 individual fish represented by nodes. In all networks, nodes from Bahia Kino are coded red, and nodes from Puerto Libertad are blue. The weight of each link is proportional to the strength of the connection. Individual fishers are linked to individual fishing sites (Social-Ecological links 1) and to individual fish (Social-Ecological link 2). Note that Social-Ecological link information was available from only 10 individual fishers (larger nodes).

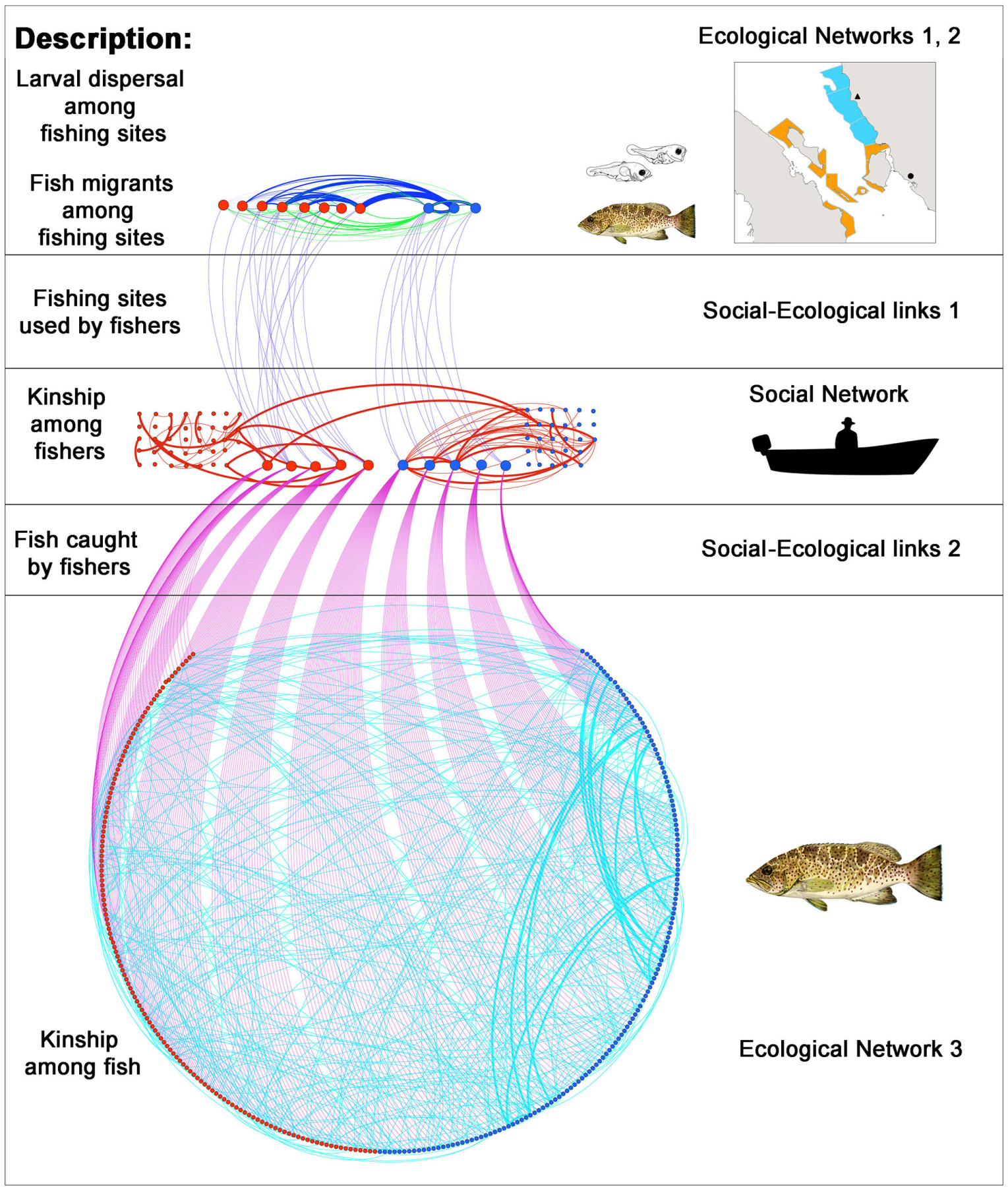




\section{DISCUSSION}

This study applied a collaborative approach merging citizen science, population genetics, oceanographic modeling, and interviews. We showed how empirical estimates of multiple ecological and social connections in the harvesting of a marine resource can be estimated and integrated for analysis of the interactions within the conceptual framework of multiple onelevel networks that could be assembled into a multilevel socialecological network. However, our ability to measure explicit social-ecological links was limited by the small number of fishers from whom ecological data was acquired. Also, the statistical comparison of properties of ecological and social networks displaying drastically different sizes is problematic. Below, we discuss some insights learned while comparing the level of ecological and social connectivity and challenges identified. We also examine some patterns observed on the constraints of connectivity given different attributes of each ecological and social component. Finally, we discuss how this information could be used to inform ways to improve collaborative management.

Although we showed detailed connections within ecological and social levels and between the two levels, a fully articulated socialecological multilevel network typically considers all links simultaneously (Bodin 2017, Sayles et al. 2019). The number of fishers involved in the citizen science program in our study was limited to five fishers from each community. Thus, the information gathered about explicit social-ecological links represents only 10 individual fishers from a much larger universe. The effort to empirically characterize even a modest number of relevant socialecological links grows exponentially with the number of fishers, fish, and fishing zones and seems daunting even for a single species and two communities. Thus, novel approaches would need to be developed in order to quickly and massively characterize ecological connections among multiple fish populations, for example, via environmental DNA metabarcoding (Sigsgaard et al. 2020; Valdivia-Carrillo et al. 2021). Additionally, we did not consider ecological connections for leopard grouper from other adjacent fishing communities (e.g., Bahía de los Angeles and Puerto Peñasco) that show significant import or export of larvae from/toward BK and PL fishing sites (Munguia-Vega et al. 2014, Jackson et al. 2015). These observations stress the problem of defining boundaries of social-ecological networks, which alter the number of nodes and the properties of the networks being studied.

\section{Social-ecological links between communities}

The scientific literature recognizes a lack of consensus about what constitutes social-ecological fit and how and at which scales it should be better measured (Bodin et al. 2019). Compared to previous studies of social-ecological networks in fisheries that focused on trophic relationships among targeted species and resource users (Yletyinen et al. 2018, Barnes et al. 2019, Kluger et al. 2019), our study highlighted source-sink metapopulation dynamics for a species with a complex life history at the level of individual fish, fishers, and fishing sites. However, even when networks are a flexible tool for investigating diverse types of data, a key challenge remains in performing quantitative analyses to compare connections in mixed social-ecological networks (Janssen et al. 2006). Our approach attempted a quantitative comparison of the likelihood of finding ecological and social links employing network density as a common measure to compare disparate networks. In our statistical analyses, ecological links between fishing sites from the two communities were more likely to be present than any social tie among fishers. For example, in a direct comparison of the same variable (kinship) between individual fish and fishers from the two communities, kinship was an order of magnitude less likely to be present between fishers compared to fish. So, although not completely absent, social ties between the two communities were weak compared to ecological links. These results suggest little mobility of individual fishers between the two communities despite significant movement of leopard groupers through their life cycle between fishing sites. Thus, the geographic scale and strength of key ecological processes supporting fish stocks through the fish life cycle seem to be larger than those of social connections among resource users. This suggests some level of governance challenge due to a lack of network closure, where the two actors exploiting interconnected ecological resources lack strong collaboration (Bodin et al. 2016). Resource users and managers could benefit from a broader, regional perspective that connects fishers from distinct communities toward shared goals and activities, e.g., monitoring of stock status and management actions. However, a key challenge in establishing mismatches between ecological and social networks is the resolution of what the nodes and links represent in the network. For example, in our study there was an order of magnitude difference between the number of fishing sites (11), fishers (83), and fish (282). The number of nodes in the network defines the number of potential links present, thus density in a network decreases exponentially with increasing network size. This bias could also contribute to the fact that probabilities of finding ecological links among fishing sites were an order of magnitude larger than the probability of finding any social ties. Alternative analytical methods to compare socialecological networks include motif frequency counts (e.g., of closed network structures) and exponential random graph modeling (ERGM) to test against a null model assuming a uniform likelihood of finding links between nodes (Barnes et al. 2019, Sayles et al. 2019).

Our study revealed strong leopard grouper connectivity between two communities of fishers, even when they were geographically distant (150 km apart), targeted different cohorts of the same species using distinct fishing gear, and used completely different fishing zones that do not show any spatial overlap. The latter could be explained by the presence of valuable fishing zones closer to home, the use of different fishing gear targeting distinct cohorts, and informal agreements about the traditional fishing zones of each community. Ecological links between the two communities were within the same order of magnitude and equally or more likely to be present compared to links within each community. The relevance of ecological connections between the fishing zones from the two communities varied along the life history of the fish, creating a reciprocal ecological relationship in terms of sourcesink metapopulation dynamics. The ecological network based on larval dispersal showed BK fishing zones as a source of larvae for PL fishing grounds following the predominantly cyclonic circulation of oceanic currents during the spawning season of leopard groupers in the study region (Munguia-Vega et al. 2014). In contrast, the analysis of migrants suggested that larvae, juvenile, and adult fish from the fishing zones of PL also migrate to BK fishing grounds. Thus, management decisions that occur within the fishing zone of one community and that directly affect 
the size and reproductive potential of the fish stock can have strong demographic impacts on the availability of leopard grouper in the other community. For example, overfishing in the fishing zones of BK could negatively impact PL by reducing larval recruitment. In contrast, the recent establishment of a marine reserve in the fishing grounds of PL (DOF 2017) could translate into a spill-over effect of migrant individuals that could directly benefit BK fishers. The recognition of how local fish populations are ecologically linked to each other is essential to maintain population resilience and avoid overexploitation (Wilson 2006, Berger et al. 2017). In terms of resilience, the high density observed in the combined ecological network could suggest high resilience of the system (Janssen et al. 2006), for example, if any particular node disappears, e.g., a particular site is overfished.

In contrast to ecological links that were consistently present between the two communities, our results showed the probability of finding a social tie among fishers changed significantly depending on the type of social connection. Strong ecological connections are not echoed by strong social ties in our study system, and fishers from the two communities do not currently have stable channels for information flow. The probability of social ties was relatively modest for communication, trust, and reciprocity, significantly lower for leadership and almost absent for kinship. The likelihood of observing communication, trust, and reciprocity between the two communities was intermediate compared to the values observed within each community. Leadership and kinship ties were significantly less likely to occur between rather than within the two communities. In contrast, a previous study of social networks conducted in 2007 in the MIR found strong kinship ties between BK and PL (Duberstein 2009), highlighting that social connections evolve and might not be static over time. However, it is also likely that, by interviewing only between $10 \%$ to $17 \%$ of all the fishers from each community, we missed documenting some social connections. Notably, leadership ties were strongly biased in terms of the recognition of leaders from the smaller community according to fishers from the larger community, but not vice versa. All other social relationships observed between the two communities were symmetrical. The asymmetry could be related to the fact that fishers from the smaller community (PL) are more likely to travel to BK than the other way around because they need to report their catches at the local fisheries office from the National Fisheries and Aquaculture Commission (CONAPESCA) in BK. Overall, leaders from the smaller community seem to play a key role in bridging barriers for communication between the two communities.

Even when the fishing zones of each community regarding leopard groupers do not overlap, they do for other fisheries including gillnets targeting Pacific sierra, Pacific angel shark, and smooth-hounds, for which fishers from both communities travel to several islands in the MIR (Moreno-Báez et al. 2012). According to Duberstein (2009), fishers from PL and BK converge at 56 fishing areas, particularly in fisheries where they use gillnets and diving as fishing techniques. This indicates that the multi-species social-ecological networks are much more complex than presented here for a single species and that patterns could vary with different fishing gear. However, our approach could in principle be scaled up to integrate multiple species, communities, and fisheries. Social-ecological systems in smallscale fisheries are complex and it may be challenging to characterize each interaction and the effects they have on the environment considering small-scale fishers target dozens of different species (Leslie et al. 2015). These different species also show a large variation in life history, including habitats for recruitment, reproductive periods and planktonic larval durations, the presence of migratory behaviors, etc., that translate into contrasting patterns of ecological connectivity within each life history combination (Munguia-Vega et al. 2018). Because leopard groupers are also targeted by recreational fisheries, decisions made by small-scale fishers could affect effort, economic return, cost, fish population, and recruitment in this sector (Leslie et al. 2009). Further studies could provide direct evidence linking the structure of the social-ecological networks identified here and specific ecological and management outcomes that we did not measure, such as fish abundance, stock status, presence of cooperatives, etc.

\section{Social-ecological links within each community}

We identified that the spatial scale over which connectivity occurs, the size of the population from which the sample is drawn, and the spatial resolution of the analyses (defined by the number of nodes present in the networks) exerted a large influence on various aspects of social and ecological connectivity. For example, the results of kinship analyses among fishers within each community were similar to those of fish in that both showed a higher frequency of first-degree relatives within the smaller community (PL). This could be due to a general effect where kinship increases when the population size is smaller (Blouin 2003), which holds true for both fishers from PL and fish caught in their fishing zones that, comparatively, were also much smaller compared to the larger community.

The strength of the ecological connections was the result of the interaction between the geographic scales of the fished areas and the spatial scale at which leopard grouper individuals move, first as larvae, e.g., hundreds of kilometers, then as adults, e.g., tens of kilometers (Munguia-Vega et al. 2018). For example, in the eight fishing areas of BK spread over multiple islands of the MIR, ecological links based on larval dispersal were more likely to occur than links from migrants that include juvenile and adult dispersal. In contrast, both larval and migrant links were equally likely among the three adjacent fishing zones from PL. The observation of larger fishing areas in BK agrees with a previous study documenting travel distances up to $200 \mathrm{~km}$, compared to the other communities in the northern GC (Duberstein 2009, Moreno-Báez et al. 2012). The higher competition within a larger community could force fishers to take longer trips to distant fishing zones if local resources have been overexploited.

We found that all different types of social connections studied, including kinship, communication, trust, reciprocity, and leadership, were all equally likely to be present in the smaller community (PL), whereas in the larger community (BK) the probability of finding distinct social ties varied significantly. This observation is consistent with several studies showing a positive relationship between the degree of cooperation within a group and the level of kinship (Smith 2014, Enke 2018), which could explain the presence of robust social ties for all types of social connections investigated within PL. In contrast, in the larger community it was more likely to find a leadership tie than a kinship tie among fishers, and comparatively it was even less likely to find 
a communication, trust, or reciprocity tie. The fact that we interviewed a larger fraction of fishers in PL $(17 \%)$ compared to BK $(10 \%)$ could also have contributed to finding stronger social links in PL. The level of leadership could be explained by the longer investment of civil society organizations in BK into capacity building for fishers to strengthen the negotiation and conflict resolution skills of individuals and cooperatives. However, leadership in BK does not translate into the same level of communication or trust. Generally, all the types of social ties were more likely to be present among fishers from the smaller community compared to the larger one. This is also in line with small group size being a strong predictor of successful governance (Ostrom 1990). Trust among local fishers (as individuals) and members of cooperatives affect fishing patterns and fisheries sustainability. As long as cooperatives and patrons find reliable local fishers to work with, they have no need to recruit outsiders, which could otherwise increase fishing pressure and the risk of overfishing, as has been extensively documented (Basurto et al. 2020).

Besides kinship and group size, a lower level of social cohesion between fishers in a large community could be driven by other demographic processes, including recent immigration. A previous study suggested that high immigration rates in BK were associated with the presence of weak norms of trust and reciprocity, and low social capital, resulting in a challenge for fishers to develop relationships and invest in building fishing co-ops (Basurto et al. 2013a). As a result, their open access status quo has led to overharvest (Basurto et al. 2013b). Similarly, high levels of trust in smaller isolated communities could be positively associated with homogeneity with respect to ethnicity and social and economic relationships (Ostrom and Walker 2003). Other factors including lower access to information and education are likely to promote stronger local norms and lower variability within a smaller and isolated community, whereas greater individuality is expected in larger and more connected areas with higher access to education and information (McClanahan and Abunge 2018).

\section{Implications for collaborative management}

The uncovering of strong reciprocal ecological connections between two communities of small-scale fisheries in the presence of relatively weak and sometimes asymmetric social ties, highlights the importance of collaboration to plan and implement commonly agreed regulations and harvesting practices to ensure sustainability. Our data suggested that fishers from these two communities do not interact with each other at sea (at least for the leopard grouper fishery), therefore we recommend the creation of new venues for collaboration or strengthening of existing collaborative efforts.

Although some settings do exist for fishers within each community to improve governance, promote sustainable practices, and work toward a common vision, formal venues for fishers from both communities to cooperate are very limited. Both communities have community committees for fisheries and aquaculture management that represent cooperatives, permit holders, and free fishers (Espinosa-Romero et al. 2014), which do not have management authority but provide a common voice to the government to request or recommend changes. Nevertheless, the two committees do not currently interact. There is often a significant difference between communities regarding the perceived costs and benefits of fishery restrictions such as size limits, closures, gear management, and others (McClanahan and Abunge 2018). Regional forums could provide an understanding of how both communities can manage their resources to maximize their shared benefits by identifying and communicating the nature and extent of ecological interactions (larval recruitment, spillover effects, and adult migration). Shared norms, social capital, and a shared governance of common resources, can only emerge from repeated and extended interactions that create interdependence and shared identities and interests among community members (McCay et al. 2014). It has been documented that fishers' participation in local fisheries management depends on the fishing access strategy they are associated with. As members of cooperatives, fishers are more likely to be able to create more trustworthy relationships and to participate in decision-making forums about fishing activities, financial distribution of benefits, working conditions, etc. (Basurto et al. 2020).

Social relations developed among individuals are part of their social capital, which enables network members to have access to different types of resources or benefits, including access to markets, increased income, and access to knowledge (PedrozaGutiérrez and Hernandez 2017). These relationships, as supported by the network exchange theory, provide a higher adaptive capacity to fishers that have a stronger and larger network, favoring those center positions compared to peripheral positions in the network (González-Mon et al. 2019). Social interactions among fishers from distinct communities are important in the face of increasing environmental variability in the Gulf of California and elsewhere (Frawley et al. 2019b). The behavior of small-scale fishers and their spatio-temporal movements respond to changes in their target fisheries (Sievanen 2014, González-Mon et al. 2021). Knowledge plays a key role in some of the most common responses of fishers to climate variability, including moving fishing locations, diversifying fisheries or occupations, or switching gear types (Sievanen 2014).

Other initiatives that already promote some collaboration between communities also include (1) underwater monitoring groups of fishers trained in SCUBA diving to help evaluate marine reserves (Fulton et al. 2019); (2) a gender equality program where men and women from several fishing communities in Mexico, including PL and BK, are trained to promote gender equity and equality; (3) fisheries improvement project (FIP) for clams (https://fisheryprogress.org/fip-profile/mexico-puerto-libertadclams-hookah), where some fishers from BK and PL participate with government agencies from the fisheries sector.

In November 2017, the results of this study were presented separately to fishers from BK and PL. Both communities were receptive and expressed the importance of having stronger communication to collaborate with fishers from the other community. The information about how an individual fish they captured at a particular fishing site was a close relative of another fish captured by a fisher from the same or adjacent community resonated the most in terms of their appreciation of socialecological connections. This unexpected response is consistent with the presence of alternative relational values between fishers and tangible ecological elements, as opposed to theoretical or conceptual generalizations (Chan et al. 2016). They were both interested in meeting to establish agreements (i.e., pricing, size 
limits, fishing effort) regarding the leopard grouper and other fisheries they share. Exchanges are well-documented tools for promoting learning, understanding, and knowledge transfer (Gardner et al. 2017, Thompson et al. 2017). However, within a particular region, they can be effective tools in creating unity, empathy, and changing the mental model about the ecological interdependence between adjacent communities. Fishers who share a resource but are unfamiliar with how neighboring communities live and work will be less likely to consider them when making decisions that affect the fishery. The recognition of some ecological interactions can significantly contribute to the understanding and management of ecosystems, thus more intensively managing these interactions, particularly for key functional taxa such as the leopard grouper, can help resource users plan local adaptations to local problems (McClanahan et al. 2009). Other examples of successful co-management exist in the region, where a concession system for benthic resources promotes cooperatives from neighboring communities to closely collaborate (McCay et al. 2014).

In the management of fisheries, as in other common property resources, there has been a shift from agreements between two sectors (fishers and government) to co-management agreements between multiple sectors involved in the use of fishery resources (Gibbs 2008, Ponce-Diaz et al. 2009). In many cases, fisheries management changed from a hierarchical to a network structure. Instead of the government agencies being the only ones that dictate the rules, the different institutions communicate with each other to reach agreements that regulate the activity (Pomeroy 2003). Thus, the current global trend in fisheries systems is toward a reticular structure. Central actors, identified in our study as fishers from PL, have more social ties than others and are well situated to execute leadership that facilitates regional collective action. Regional committees, including fishers from other fishing communities beyond PL and BK could also help create dialogue spaces for resource users at the scale at which ecological connections are present.

Responses to this article can be read online at: https://www.ecologyandsociety.org/issues/responses. php/13055

\section{Acknowledgments:}

Research was made possible through the generous support of Bennett and Jacquie Dorrance. Comunidad y Biodiversidad A.C. received funding from the David and Lucile Packard Foundation, the Marisla Foundation, the Sandler Supporting Family Foundation, and the Walton Family Foundation. The Nature Conservancy received funding for this project from Fundacion Televisa. We thank the fishers who participated in the citizen science program and helped us to collect samples and data in the field, David Paz-García and Eric Ramírez-Saucedo for their support during DNA extraction and microsatellite genotyping, and Mario VergaraRodarte for conversations that improved the project. AMV and $J A Z D$ worked as consultants for Comunidad y Biodiversidad A.C. for this project. We also thank the contributions by three anonymous reviewers and the subject editor that helped to improve the manuscript.

\section{Data Availability:}

The data supporting the findings of this study are available as Supplementary Material.

\section{LITERATURE CITED}

Aljanabi, S. M., and I. Martinez. 1997. Universal and rapid saltextraction of high quality genomic DNA for PCR-based techniques. Nucleic Acids Research 25:4692-4693. https://doi. org/10.1093/nar/25.22.4692

Alvarez-Romero, J. G., A. Munguia-Vega, M. Beger, M. M. Mancha-Cisneros, A. N. Suárez-Castillo, G. G. Gurney, R. L. Pressey, L. R. Gerber, H. N. Morzaria-Luna, H. Reyes-Bonilla, V. M. Adams, M. Kolb, E. M. Graham, J. VanDerWal, A. H.-A. Castillo-Lopez, G. D. Petatan-Ramirez, M. Moreno-Baez, C. R. Godinez-Reyes, and J. Torre. 2018. Designing connected marine reserves in the face of global warming. Global Change Biology 24:e671-e691. https://doi.org/10.1111/gcb.13989

Alvarez-Romero, J. G., R. L. Pressey, N. C. Ban, J. Torre-Cosio, and O. Aburto-Oropeza. 2013. Marine conservation planning in practice: lessons learned from the Gulf of California. Aquatic Conservation: Marine and Freshwater Ecosystems 23:483-505. https://doi.org/10.1002/aqc.2334

Barnes, M. L., O. Bodin, T. R. McClanahan, J. N. Kittinger, A. S. Hoey, O. G. Gaoue, and N. A. J. Graham. 2019. Socialecological alignment and ecological conditions in coral reefs. Nature Communications 10:2039. https://doi.org/10.1038/ s41467-019-09994-1

Bastian, M., S. Heymann, and M. Jacomy. 2009. Gephi: An open source software for exploring and manipulating networks. Proceedings of the Third International ICWSM Conference: 361-362.

Basurto, X., A. Bennett, A. Hudson Weaver, S. Rodriguez-Van Dyck, and J.-S. Aceves-Bueno. 2013a. Cooperative and noncooperative strategies for small-scale fisheries' selfgovernance in the globalization era: implications for conservation. Ecology and Society 18(4):38. https://doi. org/10.5751/ES-05673-180438

Basurto, X., A. Bennett, E. Lindkvist, and M. Schluter. 2020. Governing the commons beyond harvesting: an empirical illustration from fishing. PLoS ONE 15:e0231575. https://doi. org/10.1371/journal.pone.0231575

Basurto, X., S. Gelcich, and E. Ostrom. 2013b. The socialecological system framework as a knowledge classificatory system for benthic small-scale fisheries. Global Environmental Change 23:1366-1380. https://doi.org/10.1016/j.gloenvcha.2013.08.001

Berger, A. M., D. R. Goethel, P. D. Lynch, T. Quinn, S. Mormede, J. McKenzie, and A. Dunn. 2017. Space oddity: the mission for spatial integration. Canadian Journal of Fisheries and Aquatic Sciences 74:1698-1716. https://doi.org/10.1139/cjfas-2017-0150 
Blouin, M. 2003. DNA-based methods for pedigree reconstruction and kinship analysis in natural populations. Trends in Ecology and Evolution 18:503-511. https://doi. org/10.1016/S0169-5347(03)00225-8

Bodin, Ö. 2017. Collaborative environmental governance: achieving collective action in social-ecological systems. Science 357(6352):eaan1114. https://doi.org/10.1126/science.aan1114

Bodin, Ö., S. M. Alexander, J. Baggio, M. L. Barnes, R. Berardo, G. S. Cumming, L. E. Dee, A. P. Fischer, M. Fischer, M. Mancilla Garcia, A. M. Guerrero, J. Hileman, K. Ingold, P. Matous, T. H. Morrison, D. Nohrstedt, J. Pittman, G. Robins, and J. S. Sayles . 2019. Improving network approaches to the study of complex social-ecological interdependencies. Nature Sustainability 2:551-559. https://doi.org/10.1038/s41893-019-0308-0

Bodin, Ö., and B. I. Crona. 2008. Management of natural resources at the community level: exploring the role of social capital and leadership in a rural fishing community. World Development 36:2763-2779. https://doi.org/10.1016/j.worlddev.2007.12.002

Bodin, Ö., and B. I. Crona. 2009. The role of social networks in natural resource governance: what relational patterns make a difference? Global Environmental Change 19:366-374. https:// doi.org/10.1016/j.gloenvcha.2009.05.002

Bodin, Ö., G. Robins, R. R. J. McAllister, A. M. Guerrero, B. Crona, M. Tengö, and M. Lubell. 2016. Theorizing benefits and constraints in collaborative environmental governance: a transdisciplinary social-ecological network approach for empirical investigations. Ecology and Society 21(1):40. https:// doi.org/10.5751/ES-08368-210140

Bonacich, P., and P. Lloyd. 2001. Eigenvector-like measures of centrality for asymmetric relations. Social Networks 23:191-201. https://doi.org/10.1016/S0378-8733(01)00038-7

Borgatti, S. P., M. G. Everett, and L. C. Freeman. 2002. UCINET for windows: software for social network analysis. Analytical Technologies, Harvard, Massachusetts, USA.

Borgatti, S. P., A. Mehra, D. J. Brass, and G. Labianca. 2009. Network analysis in the social sciences. Science 323:892-895. https://doi.org/10.1126/science.1165821

Chan, K. M., P. Balvanera, K. Benessaiah, M. Chapman, S. Diaz, E. Gomez-Baggethun, R. Gould, N. Hannahs, K. Jax, S. Klain, G. W. Luck, B. Martin-López, B. Muraca, B. Norton, K. Ott, U. Pascual, T. Satterfield, M. Tadaki, J. Taggart, and N. Turner. 2016. Opinion: Why protect nature? Rethinking values and the environment. Proceedings of the National Academy of Sciences 113:1462-1465. https://doi.org/10.1073/pnas.1525002113

Cinti, A., J. N. Duberstein, E. Torreblanca, and M. Moreno-Báez. 2014. Overfishing drivers and opportunities for recovery in smallscale fisheries of the Midriff Islands Region, Gulf of California, Mexico: the roles of land and sea institutions in fisheries sustainability. Ecology and Society 19(1):15. https://doi. org/10.5751/ES-05570-190115

Cox, J. C. 2004. How to identify trust and reciprocity. Games and Economic Behavior 46:260-281. https://doi.org/10.1016/S0899-8256 (03)00119-2
Cumming, G. S., D. H. M. Cumming, and C. L. Redman. 2006. Scale mismatches in social-ecological systems: causes, consequences, and solutions. Ecology and Society 11(1):14. https://doi.org/10.5751/ES-01569-110114

Cumming, G. S., and K. A. Dobbs. 2020. Quantifying socialecological scale mismatches suggests people should be managed at broader scales than ecosystems. One Earth 3:251-259. https:// doi.org/10.1016/j.oneear.2020.07.007

d'Armengol, L., M. Prieto Castillo, I. Ruiz-Mallén, and E. Corbera. 2018. A systematic review of co-managed small-scale fisheries: social diversity and adaptive management improve outcomes. Global Environmental Change 52:212-225. https://doi. org/10.1016/j.gloenvcha.2018.07.009

Diario Oficial de la Federación (DOF). 2017. Acuerdo por el que se establece una zona de refugio pesquero total temporal en aguas marinas de jurisdicción federal de Puerto Libertad, municipio de Pitiquito en el estado de Sonora. Diario Oficial de la Federación, México. [online] URL: http://dof.gob.mx/nota detalle.php? $\underline{\text { codig }_{0}=5489928 \& \text { fech }=12 / 07 / 2017}$

Diaz-Uribe, J. G., J. F. Elorduy-Garay, and M. T. GonzalezValdovinos. 2001. Age and growth of the leopard grouper, Mycteroperca rosacea, in the southern Gulf of California, Mexico. Pacific Science 55:171-182. https://doi.org/10.1353/ psc. 2001.0012

Duberstein, J. N. 2009. The shape of the commons: social networks and the conservation of small-scale fisheries in the Northern Gulf of California, Mexico. Dissertation. School of Natural Resources and the Environment, University of Arizona, Tucson, Arizona, USA.

Enke, B. 2018. Kinship systems, cooperation, and the evolution of culture. CESifo Working Paper. Category 13: Behavioural Economics 6867:1-116. https://doi.org/10.2139/ssrn.3144249

Epstein, G., J. Pittman, S. M. Alexander, S. Berdej, T. Dyck, U. Kreitmair, K. J. Rathwell, S. Villamayor-Tomas, J. Vogt, and D. Armitage. 2015. Institutional fit and the sustainability of socialecological systems. Current Opinion in Environmental Sustainability 14:34-40. https://doi.org/10.1016/j.cosust.2015.03.005

Erisman, B., and M. Craig. 2018. Mycteroperca rosacea. The IUCN Red List of Threatened Species. https://dx.doi. org/10.2305/IUCN.UK.2018-2.RLTS.T14053A100466656.en

Erisman, B., I. Mascarenas, G. Paredes, Y. Sadovy de Mitcheson, O. Aburto-Oropeza, and P. Hastings. 2010. Seasonal, annual, and long-term trends in commercial fisheries for aggregating reef fishes in the Gulf of California, Mexico. Fisheries Research 106:279-288. https://doi.org/10.1016/j.fishres.2010.08.007

Espinosa-Romero, M. J., M. A. Cisneros-Mata, T. McDaniels, and J. Torre. 2014. Aplicación del enfoque ecosistémico al manejo de pesquerías artesanales. Caso de estudio: Puerto libertad, Sonora. Ciencia Pesquera 22:65-67.

Fernandez-Rivera Melo, F. J., A. N. Suarez-Castillo, I. G. Amador-Castro, E. Gastelum-Nava, M. J. Espinosa-Romero, and J. Torre. 2018. Bases para el ordenamiento de la pesca artesanal con la participación del sector productivo en la región de las grandes islas, Golfo de California. Ciencia Pesquera 26:81-100. 
Fontana, A., and J. H. Frey. 2005. The interview: from neutral stance to political involvement. Pages 695-727 in N. K. Denzin, and Y. S. Lincoln, editors. The SAGE handbook of qualitative research. SAGE, Thousand Oaks, California, USA.

Food and Agriculture Organization (FAO). 2020. The state of world fisheries and aquaculture 2020. FAO, Rome, Italy.

Frawley, T. H., D. K. Briscoe, P. C. Daniel, G. L. Britten, L. B. Crowder, C. J. Robinson, W. F. Gilly, and A. Arkhipkin. 2019b. Impacts of a shift to a warm-water regime in the Gulf of California on jumbo squid (Dosidicus gigas). ICES Journal of Marine Science 76:2413-2426. https://doi.org/10.1093/icesjms/ $\underline{\text { fsz133 }}$

Frawley, T. H., E. M. Finkbeiner, and L. B. Crowder. 2019a. Environmental and institutional degradation in the globalized economy: lessons from small-scale fisheries in the Gulf of California. Ecology and Society 24(1):7. https://doi.org/10.5751/ ES-10693-240107

Fuller, E. C., J. F. Samhouri, J. S. Stoll, S. A. Levin, and J. R. Watson. 2017. Characterizing fisheries connectivity in marine social-ecological systems. ICES Journal of Marine Science 74:2087-2096. https://doi.org/10.1093/icesjms/fsx128

Fulton, S., A. Hernández-Velasco, A. Suarez-Castillo, F. F.-R. Melo, M. Rojo, A. Sáenz-Arroyo, A. H. Weaver, R. CudneyBueno, F. Micheli, and J. Torre. 2019. From fishing fish to fishing data: the role of artisanal fishers in conservation and resource management in Mexico. Pages 151-175 in S. Salas, M. J. BarraganPaladines, and R. Chuenpagdee, editors. Viability and sustainability of small-scale fisheries in Latin America and the Caribbean. Springer, Cham, Switzerland. https://doi. org/10.1007/978-3-319-76078-0 7

Gardner, C. J., J. E. Latham, and S. Rocliffe. 2017. Intended and unintended outcomes in fisheries learning exchanges: lessons from Mexico and Madagascar. Marine Policy 77:219-226. https:// doi.org/10.1016/j.marpol.2016.04.040

Gibbs, M. T. 2008. Network governance in fisheries. Marine Policy 32:113-119. https://doi.org/10.1016/j.marpol.2007.05.002

González-Mon, B., Ö. Bodin, B. Crona, M. Nenadovic, and X. Basurto. 2019. Small-scale fish buyers' trade networks reveal diverse actor types and differential adaptive capacities. Ecological Economics 164:106338. https://doi.org/10.1016/j.ecolecon.2019.05.018

Gonzalez-Mon, B., Ö. Bodin, E. Lindkvist, T. H. Frawley, A. Giron-Nava, X. Basurto, M. Nenadovic, and M. Schlüter. 2021. Spatial diversification as a mechanism to adapt to environmental changes in small-scale fisheries. Environmental Science and Policy 116:246-257. https://doi.org/10.1016/j.envsci.2020.11.006

Green, A. L., A. P. Maypa, G. R. Almany, K. L. Rhodes, R. Weeks, R. A. Abesamis, M. G. Gleason, P. J. Mumby, and A. T. White. 2015. Larval dispersal and movement patterns of coral reef fishes, and implications for marine reserve network design. Biological Reviews of the Cambridge Philosophical Society 90:1215-1247. https://doi.org/10.1111/brv.12155

Hanneman, R. A., and M. Riddle. 2005. Introduction to social network methods. University of California, Riverside, California, USA.
Hartley, T. W. 2010. Fishery management as a governance network: examples from the Gulf of Maine and the potential for communication network analysis research in fisheries. Marine Policy 34:1060-1067. https://doi.org/10.1016/j.marpol.2010.03.005

Henry, A. D., and T. Dietz. 2011. Information, networks, and the complexity of trust in commons governance. International Journal of the Commons 5:188-212. https://doi.org/10.18352/ ijc. 312

Hilborn, R., R. O. Amoroso, C. M. Anderson, J. K. Baum, T. A. Branch, C. Costello, C. L. de Moor, A. Faraj, D. Hively, O. P. Jensen, H. Kurota, L. R. Little, P. Mace, T. McClanahan, M. C. Melnychuk, C. Minto, G. C. Osio, A. M. Parma, M. Pons, S. Segurado, C. S. Szuwalski, J. R. Wilson, and Y. Ye. 2020. Effective fisheries management instrumental in improving fish stock status. Proceedings of the National Academy of Sciences 117:2218-2224. https://doi.org/10.1073/pnas.1909726116

Jackson, A. M., A. Munguía-Vega, R. Beldade, B. E. Erisman, and G. Bernardi. 2015. Incorporating historical and ecological genetic data for leopard grouper (Mycteroperca rosacea) into marine reserve design in the Gulf of California. Conservation Genetics 16:811-822. https://doi.org/10.1007/s10592-015-0702-8

Jackson, A. M., A. Munguia-Vega, A. Lain, S. Stokes, A. Williams, and G. Bernardi. 2014. Isolation and characterization of fifteen microsatellite loci in leopard grouper (Mycteroperca rosacea) via 454 pyrosequencing. Conservation Genetics Resources 6:185-187. https://doi.org/10.1007/s12686-013-0044-0

Janssen, M. A., Ö. Bodin, J. M. Anderies, T. Elmqvist, H. Ernstron, R. R. J. McAllister, P. Olsson, and P. Ryan. 2006. Toward a network perspective on the resilience of socialecological systems. Ecology and Society 11(1):15. https://doi. org/10.5751/ES-01462-110115

Johnson, A. F., M. Moreno-Báez, A. Giron-Nava, J. Corominas, B. Erisman, E. Ezcurra, and O. Aburto-Oropeza. 2017. A spatial method to calculate small-scale fisheries effort in data poor scenarios. PLoS ONE 12:e179114. https://doi.org/10.1371/ journal.pone.0174064

Jones, G. P., G. R. Almany, G. R. Russ, P. F. Sale, R. S. Steneck, M. J. H. Oppen, and B. L. Willis. 2009. Larval retention and connectivity among populations of corals and reef fishes: history, advances and challenges. Coral Reefs 28:307-325. https://doi. org/10.1007/s00338-009-0469-9

Jones, O. R., J. Wang. 2010. Colony: a program for parentage and sibship inference from multilocus genotype data. Molecular Ecology Resources 10:551-555. https://doi.org/10.1111/ j.1755-0998.2009.02787.x

Kluger, L. C., M. Scotti, I. Vivar, and M. Wolff. 2019. Specialization of fishers leads to greater impact of external disturbance: evidence from a social-ecological network modelling exercise for Sechura Bay, Northern Peru. Ocean \& Coastal Management 179:104861. https://doi.org/10.1016/j. ocecoaman.2019.104861

Leslie, H., X. Basurto, M. Nenadovic, L. Sievanen, K. C. Cavanaugh, J. J. Cota-Nieto, B. E. Erisman, E. Finkbeiner, G. Hinojosa-Arango, M. Moreno-Báez, S. Nagavarapu, S. M. W. 
Reddy, A. Sánchez-Rodríguez, K. Siegel, J. J. UlibarriaValenzuela, A. Hudson Weaver, and O. Aburto-Oropeza. 2015. Operationalizing the social-ecological systems framework to assess sustainability. Proceedings of the National Academy of Sciences 112:5979-5984. https://doi.org/10.1073/pnas.1414640112

Leslie, H. M., M. Schlüter, R. Cudney-Bueno, and S. A. Levin. 2009. Modeling responses of coupled social-ecological systems of the Gulf of California to anthropogenic and natural perturbations. Ecological Research 24:505-519. https://doi. org/10.1007/s11284-009-0603-8

Lindkvist, E., X. Basurto, and M. Schluter. 2017. Micro-level explanations for emergent patterns of self-governance arrangements in small-scale fisheries: a modeling approach. PLoS ONE 12:e0179439. https://doi.org/10.1371/journal.pone.0179439

McCay, B. J., F. Micheli, G. Ponce-Díaz, G. Murray, G. Shester, S. Ramirez-Sanchez, and W. Weisman. 2014. Cooperatives, concessions, and co-management on the Pacific coast of Mexico. Marine Policy 44:49-59. https://doi.org/10.1016/j.marpol.2013.08.001

McClanahan, T. R., and C. A. Abunge. 2018. Demographic variability and scales of agreement and disagreement over resource management restrictions. Ecology and Society 23(4):33. https://doi.org/10.5751/ES-10544-230433

McClanahan, T. R., J. C. Castilla, A. T. White, and O. Defeo. 2009. Healing small-scale fisheries by facilitating complex socioecological systems. Reviews in Fish Biology and Fisheries 19:33-47. https://doi.org/10.1007/s11160-008-9088-8

Moreno, C., A. Weaver, L. Bourillon, J. Torre, J. Egido, and M. Rojo. 2005. Diagnóstico ambiental y socioeconómico de la región marina-costera de Bahía de Kino, isla Tiburón, Sonora México: Documento de trabajo y discusión para promover un desarrollo sustentable. Comunidad y biodiversidad A.C., Guaymas, Sonora, Mexico.

Moreno-Báez, M., R. Cudney-Bueno, B. J. Orr, W. W. Shaw, T. Pfister, J. Torre-Cosio, R. Loaiza, and M. Rojo. 2012. Integrating the spatial and temporal dimensions of fishing activities for management in the northern Gulf of California, Mexico. Ocean \& Coastal Management 55:111-127. https://doi.org/10.1016/j. ocecoaman.2011.10.001

Morzaria-Luna, H., P. Turk-Boyer, E. I. Polanco-Mizquez, C. Downton-Hoffmann, G. Cruz-Piñón, T. Carrillo-Lammens, R. Loaiza-Villanueva, P. Valdivia-Jiménez, A. Sánchez-Cruz, V. Peña-Mendoza, A. M. López-Ortiz, V. Koch, L. Vázquez-Vera, J. A. Arreola-Lizárraga, I. G. Amador-Castro, A. N. Suárez Castillo, and A. Munguia-Vega. 2020. Coastal and marine spatial planning in the northern Gulf of California, Mexico: consolidating stewardship, property rights, and enforcement for ecosystem-based fisheries management. Ocean \& Coastal Management 197:105316. https://doi.org/10.1016/j. ocecoaman.2020.105316

Munguia-Vega, A., A. L. Green, A. N. Suarez-Castillo, M. J. Espinosa-Romero, O. Aburto-Oropeza, A. M. CisnerosMontemayor, G. Cruz-Piñón, D. G. Danemann, A. Giron-Nava, O. T. Gonzalez-Cuellar, C. Lasch, M. M. Mancha-Cisneros, S. G. Marinone, M. Moreno-Baez, H. Morzaria-Luna, H. Reyes-
Bonilla, J. Torre, P. Turk-Boyer, M. Walther, and A. W. Hudson. 2018. Ecological guidelines for designing networks of marine reserves in the unique biophysical environment of the Gulf of California. Reviews in Fish Biology and Fisheries 28:749-776. https://doi.org/10.1007/s11160-018-9529-y

Munguia-Vega, A., A. Jackson, S. G. Marinone, B. Erisman, M. Moreno-Baez, A. Girón-Nava, T. Pfister, O. Aburto-Oropeza, and J. Torre. 2014. Asymmetric connectivity of spawning aggregations of a commercially important marine fish using a multidisciplinary approach. PeerJ 2:e511. https://doi.org/10.7717/ peeri. 511

Munguia-Vega, A., J. Torre, P. Turk-Boyer, S. G. Marinone, M. F. Lavin, T. Pfister, W. Shaw, G. Danemann, P. Raimondi, A. Castillo-López, A. Cinti, J. N. Durberstein, M. Moreno-Báez, M. Rojo, G. Soria, L. Sánchez-Velasco, H. N. Morzaria-Luna, L. Bourillón, K. Rowell, and R. Cudney-Bueno. 2015. PANGAS: An interdisciplinary ecosystem-based research framework for small-scale fisheries in the northern Gulf of California. Journal of the Southwest 57:337-390. https://doi.org/10.1353/jsw.2015.0003

Newman, M. E. J. 2003. The structure and function of complex networks. SIAM Review 45:167-256. https://doi.org/10.1137/ $\underline{\mathrm{S} 003614450342480}$

Ostrom, E. 1990. Governing the commons: the evolution of institutions for collective action. Cambridge University Press, Cambridge, UK. https://doi.org/10.1017/CBO9780511807763

Ostrom, E. 2009. A general framework for analyzing sustainability of social-ecological systems. Science 325:419-422. https://doi.org/10.1126/science.1172133

Ostrom, E., and J. Walker. 2003. Trust and reciprocity: interdisciplinary lessons for experimental research. Russell Sage Foundation, New York, New York, USA.

Pauly, D., and D. Zeller. 2016. Catch reconstructions reveal that global marine fisheries catches are higher than reported and declining. Nature Communications 7:10244. https://doi. org/10.1038/ncomms 10244

Pedroza-Gutiérrez, C., and J. M. Hernandez. 2017. Social networks, market transactions, and reputation as a central resource. The Mercado del Mar, a fish market in central Mexico. PLoS ONE 12:e186063. https://doi.org/10.1371/journal. pone. 0186063

Pikitch, E. K., C. Santora, E. A. Babcock, A. Bakun, R. Bonfil, D. O. Conover, P. K. Dayton, P. Doukakis, D. Fluharty, B. Heneman, E. D. Houde, J. Link, P. A. Livingston, M. Mangel, M. K. McAllister, J. Pope, and K. J. Sainsbury. 2004. Ecosystembased fishery management. Science 305:346-347. https://doi. org/10.1126/science.1098222

Piry, S., A. Alapetite, J. M. Cornuet, D. Paetkau, L. Baudouin, and A. Estoup. 2004. GENECLASS2: a software for genetic assignment and first-generation migrant detection. Journal of Heredity 95:536-539. https://doi.org/10.1093/jhered/esh074

Pomeroy, R. S. 2003. The government as a partner in comanagement. Pages 247-261 in D. C. Wilson, J. R. Nielsen, and P. Degnbol, editors. The fisheries co-management experience: accomplishment, challenges and prospects. Springer, Dordrecht, The Netherlands. https://doi.org/10.1007/978-94-017-3323-6 15 
Ponce-Diaz, G., W. Weisman, and B. McCay. 2009. Coresponsibility and participation in fisheries management in Mexico: lessons from Baja California Sur. Pesca y Conservacion $1: 1-9$.

Prell, C. 2012. Social network analysis: history, theory \& methodology. SAGE, London, UK.

Prell, C., K. Hubacek, C. Quinn, and M. Reed. 2008. 'Who's in the network?' When stakeholders influence data analysis. Systemic Practice and Action Research 21:443-458. https://doi. org/10.1007/s11213-008-9105-9

Quentin Grafton, R., T. Kompas, R. McLoughlin, and N. Rayns. 2007. Benchmarking for fisheries governance. Marine Policy 31:470-479. https://doi.org/10.1016/j.marpol.2006.12.007

Rannala, B., and J. L. Mountain. 1997. Detecting immigration by using multilocus genotypes. Proceedings of the National Academy of Sciences 94:9197-9201. https://doi.org/10.1073/ pnas.94.17.9197

Raymond, M., and F. Rousset. 1995. Genepop (version 1.2): population genetics software for exact tests and ecumenicism. Journal of Heredity 86:248-249. https://doi.org/10.1093/ oxfordjournals.jhered.a111573

Rife, A. N., B. Erisman, A. Sanchez, O. Aburto-Oropeza. 2013. When good intentions are not enough ... Insights on networks of "paper park" marine protected areas. Conservation Letters 6:200-212. https://doi.org/10.1111/j.1755-263X.2012.00303.X

Sala, E., O. Aburto-Oropeza, G. Paredes, and G. Thompson. 2003. Spawning aggregations and reproductive behavior of reef fishes in the Gulf of California. Bulletin of Marine Science 72:103-121.

Sayles, J. S., M. Mancilla Garcia, M. Hamilton, S. M. Alexander, J. A. Baggio, A. P. Fischer, K. Ingold, G. R. Meredith, and J. Pittman. 2019. Social-ecological network analysis for sustainability sciences: a systematic review and innovative research agenda for the future. Environmental Research Letters 14:093003. https://doi.org/10.1088/1748-9326/ab2619

Sievanen, L. 2014. How do small-scale fishers adapt to environmental variability? Lessons from Baja California Sur, Mexico. Maritime Studies 13:9. https://doi.org/10.1186/ $\underline{\text { S40152-014-0009-2 }}$

Sigsgaard, E. E., M. R. Jensen, I. E. Winkelmann, P. R. Møller, M. M. Hansen, and P. F. Thomsen. 2020. Population-level inferences from environmental DNA - current status and future perspectives. Evolutionary Applications 13:245-262. https://doi. org/10.1111/eva.12882

Smith, H., and X. Basurto. 2019. Defining small-scale fisheries and examining the role of science in shaping perceptions of who and what counts: a systematic review. Frontiers in Marine Science 6:236. https://doi.org/10.3389/fmars.2019.00236

Smith, J. E. 2014. Hamilton's legacy: kinship, cooperation and social tolerance in mammalian groups. Animal Behaviour 92:291-304. https://doi.org/10.1016/j.anbehav.2014.02.029

Thompson, K. R., W. D. Heyman, S. H. Peckham, and L. D. Jenkins. 2017. Key characteristics of successful fisheries learning exchanges. Marine Policy 77:205-213. https://doi.org/10.1016/j. marpol.2016.03.019

Treml, E. A., P. I. J. Fidelman, S. Kininmonth, J. A. Ekstrom, and Ö. Bodin. 2015. Analyzing the (mis)fit between the institutional and ecological networks of the Indo-West Pacific. Global Environmental Change 31:263-271. https://doi.org/10.1016/j. gloenvcha.2015.01.012

Treml, E. A., P. N. Halpin, D. L. Urban, and L. F. Pratson. 2008. Modeling population connectivity by ocean currents, a graphtheoretic approach for marine conservation. Landscape Ecology 23:19-36. https://doi.org/10.1007/s10980-007-9138-y

Turnbull, L., M. T. Hütt, A. A. Ioannides, S. Kininmonth, R. Poeppl, K. Tockner, L. J. Bracken, S. Keesstra, L. Liu, R. Masselink, and A. J. Parsons. 2018. Connectivity and complex systems: learning from a multi-disciplinary perspective. Applied Network Science 3:11. https://doi.org/10.1007/s41109-018-0067-2

Valdivia-Carrillo, T., A. Rocha-Olivares, H. Reyes-Bonilla, J. F. Dominguez-Contreras, and A. Munguia-Vega. 2021. Integrating eDNA metabarcoding and simultaneous underwater visual surveys to describe complex fish communities in a marine biodiversity hotspot. Molecular Ecology Resources 21:1558-1574. https://doi.org/10.1111/1755-0998.13375

Wasserman, S., and K. Faust. 1994. Structural analysis in the social sciences. Social network analysis: methods and applications. Cambridge University Press, Cambridge, UK.

Wilson, J. A. 2006. Matching social and ecological systems in complex ocean fisheries. Ecology and Society 11(1):9. https://doi. org/10.5751/ES-01628-110109

Yletyinen, J., J. Hentati-Sundberg, T. Blenckner, and Ö. Bodin. 2018. Fishing strategy diversification and fishers' ecological dependency. Ecology and Society 23(3):28. https://doi. org/10.5751/ES-10211-230328

Zepeda-Dominguez, J. A., G. Ponce-Diaz, and F. J. VergaraSolana. 2017. El mapeo de actores y conformación de cuerpos de participación pesquera. Region y Sociedad 29:259-277. https:// doi.org/10.22198/rys.2017.68.a221

Zepeda-Dominguez, J. A., M. Zetina-Rejón, A. EspinozaTenorio, G. Ponce-Díaz, D. Lluch-Belda, M. J. Espinosa-Romero, J. Torre-Cosío, M. A. Cisneros-Mata. 2015. Mapeo topológico de los actores involucrados en el manejo de la pesquería de jaiba café Callinectes bellicosus en Sonora, México. Ciencia Pesquera 23:81-90.

Zetina-Rejón, M. J., J. A. Zepeda-Domínguez, M. RodríguezFuentes, and C. M. Fumero-Andreu. 2020. Stakeholder diversity correlates with governance network performance in two artisanal fisheries in northwest Mexico. Ocean \& Coastal Management 196:105313. https://doi.org/10.1016/j.ocecoaman.2020.105313 


\section{Appendix 1}

Table A1.1 Primer sequences and genetic polymorphism observed in 24 individuals from leopard grouper from Puerto Libertad among 5 microsatellite loci previously described (Jackson et al. 2014) and eight new loci described here, including repeat motif, size of the expected PCR product, range of observed allelic variation, number of observed alleles $(\mathrm{Na})$, observed $(\mathrm{Ho})$ and expected $(\mathrm{He})$ heterozygosity and $\mathrm{P}$ values for deviations from Hardy-Weinberg equilibrium (HWE): * 0.05 , $* * 0.01, * * * 0.001, \mathrm{NS}=$ not significant.

\begin{tabular}{|c|c|c|c|c|c|c|c|c|}
\hline Locus & $\begin{array}{l}\text { Repeat } \\
\text { motif }\end{array}$ & Primer Sequence (5'-3') & $\begin{array}{l}\text { Size } \\
(\mathrm{bp})\end{array}$ & $\begin{array}{l}\text { Allelic } \\
\text { range } \\
\text { (bp) }\end{array}$ & $\mathrm{Na}$ & Ho & $\mathrm{He}$ & HWE \\
\hline \multicolumn{9}{|l|}{$\begin{array}{l}\text { Jackson } \\
\text { et al. } \\
2014\end{array}$} \\
\hline Mros03 & $\mathrm{GT}_{(43)}$ & $\begin{array}{l}\text { F: CCATCATGAAGCTTTGACCA } \\
\text { R: TTGACTTTATCTCCAAGGCAAA }\end{array}$ & $104-160$ & $120-180$ & 18 & 0.944 & 0.912 & NS \\
\hline Mros05 & $\mathrm{CA}_{(36)}$ & $\begin{array}{l}\text { F: GGGACCTGAATGAGATCAACA } \\
\text { R: ATCCTCAAGGACTGCTGGTG }\end{array}$ & 117-199 & $159-200$ & 14 & 0.786 & 0.890 & NS \\
\hline Mros07 & $\mathrm{GT}_{(36)}$ & $\begin{array}{l}\text { F: CATTAGTGCTGCAAGGCTCA } \\
\text { R: CAGTGAAAGGCTTGGTGTCA }\end{array}$ & $140-216$ & $161-210$ & 15 & 0.786 & 0.908 & NS \\
\hline Mros11 & $\operatorname{TCTA}_{(19)}$ & $\begin{array}{l}\text { F: ATCGAGACGAAAGGATGCAG } \\
\text { R: TCCGTCAGCAGTTTACTCCC }\end{array}$ & 83-181 & $128-192$ & 13 & 0.706 & 0.896 & NS \\
\hline Mros 12 & $\operatorname{TAGA}_{(16)}$ & $\begin{array}{l}\text { F: GTCCTGCACTCAGCTTCCTC } \\
\text { R: TTCCATGACTGATCCAGCCT }\end{array}$ & $186-302$ & 208-289 & 16 & 0.889 & 0.901 & NS \\
\hline $\begin{array}{l}\text { New } \\
\text { loci: }\end{array}$ & & & & & & & & \\
\hline Mros 17 & $\operatorname{AAAG}_{(14)}$ & $\begin{array}{l}\text { F:CTTGTCCGAGGTAAGGCTTG } \\
\text { R:AACAGCAGTTAAGACTGTTTCTTCA }\end{array}$ & 154 & $157-182$ & 6 & 0.778 & 0.793 & NS \\
\hline $\operatorname{Mros} 18$ & $\operatorname{AGAT}_{(14)}$ & $\begin{array}{l}\text { F:TGAGATTTTACCAGATTCAAAAGTCA } \\
\text { R:TGCTCATGAATTCCTTACCTTG }\end{array}$ & 178 & $178-232$ & 8 & 0.500 & 0.837 & * \\
\hline Mros 22 & $\operatorname{AAAG}_{(12)}$ & $\begin{array}{l}\text { F:TGGGAATTGTAGGATCTGGC } \\
\text { R:GTACGTAAGGGGCATTCCAG }\end{array}$ & 213 & 210-244 & 9 & 0.824 & 0.851 & NS \\
\hline $\operatorname{Mros} 25$ & $\mathrm{AGGT}_{(12)}$ & $\begin{array}{l}\text { F:GAAGCTTGATTTAGAAGATCTTACCC } \\
\text { R:GCAAGTGCATGCGAAAATTA }\end{array}$ & 190 & $180-210$ & 7 & 0.667 & 0.684 & NS \\
\hline $\operatorname{Mros} 26$ & $\operatorname{AATC}_{(12)}$ & $\begin{array}{l}\text { F:TGGAGGCTTCAAAACTGGAG } \\
\text { R:TCACTGGCTATTCATGTGCAA }\end{array}$ & 162 & $152-176$ & 6 & 0.833 & 0.682 & NS \\
\hline $\operatorname{Mros} 27$ & $\operatorname{AGAT}_{(11)}$ & $\begin{array}{l}\text { F:TTCTACATGTAACAAATTTCCCC } \\
\text { R:TTGAGCCTCATGTGAAGCAG }\end{array}$ & 140 & $144-190$ & 8 & 0.889 & 0.855 & NS \\
\hline $\operatorname{Mros} 29$ & $\operatorname{AAAG}_{(11)}$ & $\begin{array}{l}\text { F:GATCCCTCTAAACTGTTCTTGTTG } \\
\text { R:CCTGACACTTTGGGTCCCT }\end{array}$ & 169 & $172-234$ & 8 & 0.778 & 0.793 & NS \\
\hline Mros 32 & $\operatorname{AACT}_{(11)}$ & $\begin{array}{l}\text { F:GACAACTGTTCAAGCAGGCA } \\
\text { R:TGTAAACCCATTTGGGCAAG }\end{array}$ & 205 & $206-278$ & 14 & 0.944 & 0.907 & NS \\
\hline
\end{tabular}




\section{Appendix 2}

Table A2.1 General description of the structured interview applied to 83 fishers from Bahia Kino and Puerto Libertad to measure four types of social ties: communication, trust, reciprocity and leadership. The fishers identified in this interview were then used in a second interview to identify kinship.

\begin{tabular}{|c|c|c|c|c|c|}
\hline \multirow{2}{*}{ Fisher's name } & \multicolumn{3}{|c|}{ Communication } & \multirow[t]{2}{*}{ Trust $ף$} & \multirow[t]{2}{*}{ Reciprocity| } \\
\hline & Presence† & Type $\neq$ & Frequency§ & & \\
\hline $\begin{array}{l}\text { Fisher's name or } \\
\text { nickname (clearly } \\
\text { enough to identify } \\
\text { him/her with } \\
\text { confidence) and town of } \\
\text { residency. } \\
\text { Names of those who I } \\
\text { have contact with, those } \\
\text { who I talk to and listen } \\
\text { to, etc. }\end{array}$ & $\begin{array}{l}\text { If for any reason I } \\
\text { have any kind of } \\
\text { interaction (talking, } \\
\text { selling, buying, etc.) }\end{array}$ & $\begin{array}{l}\text { Type of } \\
\text { interaction, } \\
\text { from very bad } \\
\text { to excellent }\end{array}$ & $\begin{array}{l}\text { Frequency, from very } \\
\text { rare (those actors } \\
\text { who I almost never } \\
\text { interact, to very } \\
\text { frequent (those actors } \\
\text { I interact very } \\
\text { frequently to) }\end{array}$ & $\begin{array}{l}\text { Trust, } \\
\text { confidence } \\
\text { from None (I } \\
\text { do not trust } \\
\text { him/her at all) } \\
\text { to Total trust (I } \\
\text { trust him/her } \\
\text { absolutely) }\end{array}$ & $\begin{array}{l}\text { Reciprocity, from } \\
\text { very low } \\
\text { reciprocity (I } \\
\text { treat him/her } \\
\text { very different } \\
\text { from how he/she } \\
\text { treats me) to very } \\
\text { high reciprocity } \\
\text { (I treat him/her } \\
\text { exactly as he/she } \\
\text { treats me). }\end{array}$ \\
\hline \multicolumn{6}{|c|}{ Leadership } \\
\hline $\begin{array}{l}\text { Please mention every } \\
\text { fisher who can influence } \\
\text { over your decisions or } \\
\text { can make you change } \\
\text { your mind }\end{array}$ & $\begin{array}{l}\text { Do you have any } \\
\text { interaction with this } \\
\text { person? }\end{array}$ & $\begin{array}{l}\text { Type of } \\
\text { interaction, } \\
\text { from very } \\
\text { poor to } \\
\text { excellent }\end{array}$ & $\begin{array}{l}\text { Frequency, from very } \\
\text { infrequent (those } \\
\text { actors who I almost } \\
\text { never interact, to very } \\
\text { frequent (those actors } \\
\text { I interact very } \\
\text { frequently to) }\end{array}$ & & \\
\hline $\begin{array}{l}\text { †(Yes / No) } \\
\ddagger 1 \text { (Very bad) } \\
\text { \$1 (Very rare) } \\
\text { \1 (None) to } 5 \\
\mid 1 \text { (Very Low }\end{array}$ & $\begin{array}{l}5 \text { (Excellent) } \\
5 \text { (Very Frequent) } \\
\text { Total trust) } \\
5 \text { (Very High) }\end{array}$ & & & & \\
\hline
\end{tabular}




\section{Short guide and brief instructions for the application of the interview}

The formats are simple and flexible to adapt to the language of the interviewee.

General technical considerations for interviewing.

- Review the survey format to clarify the type of answers we are looking for.

- Use jargon that facilitates communication and builds confidence.

- Record start time and end time of the interview, it must last no more than 30 minutes, after this time the information tends to lose confidence.

- Type the information from the format into a digital worksheet as soon as possible to include notes about the interview.

- If possible, scan the interviews to avoid losing any information.

Equipment.

- Logbook or printed format.

- Pens

Process.

1. Begin by greeting and clarifying the institutional support to the project by Comunidad $y$ Biodiversidad A.C.

2. It is important that all the interviewees have the same basic information. The introduction must be read to them, explaining the goals and methodology of the project "Socio-ecological Connectivity in the Midriffs Islands of the Gulf of California", and the need to gather information about social relationships between small-scale fishers targeting leopard grouper in the region.

3. Explicitly state that the information is anonymous, and that will be used only for academic purposes related to the goal of the project. If there is any doubt or intention to use it for another purpose, their explicit authorization will be requested.

4. It is important that interviewees understand the methodology, and is necessary to explain that they do not need to try to respond to what they think should happen, but what their personal experience is, that is to say, what happens at the moment, not in the past but now. If doubt persists, they can mention their experiences during the previous year.

5. It is key to explain the type of network being used, that is, an integral analysis of the network is carried out, which does not allow identifying who said what.

6 . In case there is any specific doubt, confirm answers, that is, "then we agree that ... correct?"

7. Provide e-mail, address, and cellular phone number to contact for any questions, clarifications or complaints.

8. Finish by thanking them for their time and the information provided. 


\section{General description of the interview to gather information on social connectivity}

The requested information is explained column by column. Fishers are given different options so that the interviewee responds according to what is closest to their perception.

Name. Name or nickname of the interviewee.

Town. In which village does the interviewee live?

Name every fisher with whom you have communication or contact.

Is there communication? Yes/No. If for any reason they have any contact with other actor (s), this is considered an interaction. When there is no interaction of any kind, the rest of the questions do not make sense and therefore are not asked.

i. Interaction type. Record the number associated with the answer.

1. Very bad. A very destructive relation, each one is intensely hindering the work of the other.

2. Bad. An interaction that hinders the work of the other.

3. Neutral. Interacts, but is not perceived to help or hinder.

4. Good. An interaction that favors each other's work. A supportive actor.

5. Excellent. An interaction that greatly favors each other, a very supportive actor.

ii. Frequency. Due to the unique nature of each fishery, this question was not given time units, it is only a general perception. Record the number associated with the answer.

1. Very rare. Those with whom you hardly ever interact. Keywords: very little, very rare, very occasionally.

2. Uncommon. Those actors with whom there is little interaction. Keywords: little, rare.

3. Regular or moderately frequent. Neither frequent nor infrequent. Keywords: regular, moderately, sometimes.

4. Frequent. Those with whom you interact with some regularity, frequently, often, continuously. 5 . Very frequent. Those actors with whom you interact many times more than with others. Keywords: very frequently, very often, very continuously.

iii. Trust. If the actor trusts the other, he/she feels that the other is trustworthy. Record the number associated with the answer.

1. None. Keywords: nothing, no trust, never, nothing.

2. Little. Keywords: there is little trust, seldom, almost anything, very rare, very little, etc.

3. Regular. Keywords: average trust, sometimes.

4. Trust. Keywords: there is, there is trust, I have trust, I trust him/her

5. Total trust. Keywords: a lot, full confidence, always, totally, very.

iv. Reciprocity. If the interviewee treats the other actor very similar or very different from how the other actor treats the interviewee.

1. Very low. I always treat him/her very differently from how he/she treats me.

2. Low. Most of the time I treat him/her very differently from how he/she treats me.

3. Intermediate. I treat him/her more or less the same as how he/she treats me

4. High. I treat him/her as he/she treats me most of the time.

5. Very high. I always treat him/her exactly as he/she treats me. 
v. Leadership. Name every fisher you consider influences your decisions or can make you change your mind?

Do you have any interaction with this person? Yes/No

Interaction type and Frequency as detailed above.

vi. Kinship. If the actor has a kinship or is a relative of other fisher (s) identified in the previous questions. Record the number associated with the answer.

1. First-degree relative (parent-offspring, full sibs).

2. Second-degree relative (grandparent-grandchildren, half-sibs, avuncular: uncle, aunt, nephews, nieces). 


\section{Appendix 3}

\section{Quality control in genetic analyses}

From the 776 leopard groupers sampled, we selected 500 individuals for DNA extraction and PCR amplification that met our criteria related to the candidate parents/progeny age groups, as explained in the Methods section. From these, we performed strict quality controls, since errors in genotyping and the presence of missing data can strongly bias the results of parentage and sibship analyses (Jones et al., 2010). First, we eliminated those individuals that showed low quality or quantity of genomic DNA, likely because their tissues were not properly fixed in the field and that failed to consistently amplify via PCR, as assessed by agarose gel electrophoresis. Second, we discarded individuals that failed to amplify for at least 11 microsatellite loci, those that showed more than two alleles per locus, or the presence of more than one individual DNA, indicative of DNA contamination, and those individuals for which electropherograms showed noisy or ambiguous results. Our final dataset included 282 leopard grouper individuals genotyped at 13 loci (138 from BK and 144 from PL; see Appendix 4. Figure A4.1 for sampling details and Appendix 5. Table A5.1 for the raw genotype data of each individual), with an average of $1.47 \%$ missing data. The 13 genotyped loci were highly variable, averaging 11 alleles per locus, while observed and expected heterozygosity were 0.851 and 0.825 , respectively (Appendix 6. Table A6.1). Based on the level of polymorphism, the combined genotypes for the 13 loci provided a probability of individual identity $2.0^{-22}$, and a probability of identifying full sibs of $4.3^{-7}$. From 130 tests of HWE among the 13 loci within each population, we found only two cases of significant deviations $(\mathrm{P}<0.0003)$. We did not find any significant instances of significant LD among 78 tests conducted between each pair of loci (all P values $>0.0006$ ).

\section{References:}

Jones, A. G., C. M. Small, K. A. Paczolt, and N. L. Ratterman 2010. A practical guide to methods of parentage analysis. Molecular Ecology Resources, 10: 6-30. 


\section{Appendix 4}

Figure A4.1 Number of samples of leopard groupers (shown as black numbers) collected from each of the 11 fishing areas (indicated by red numbers).

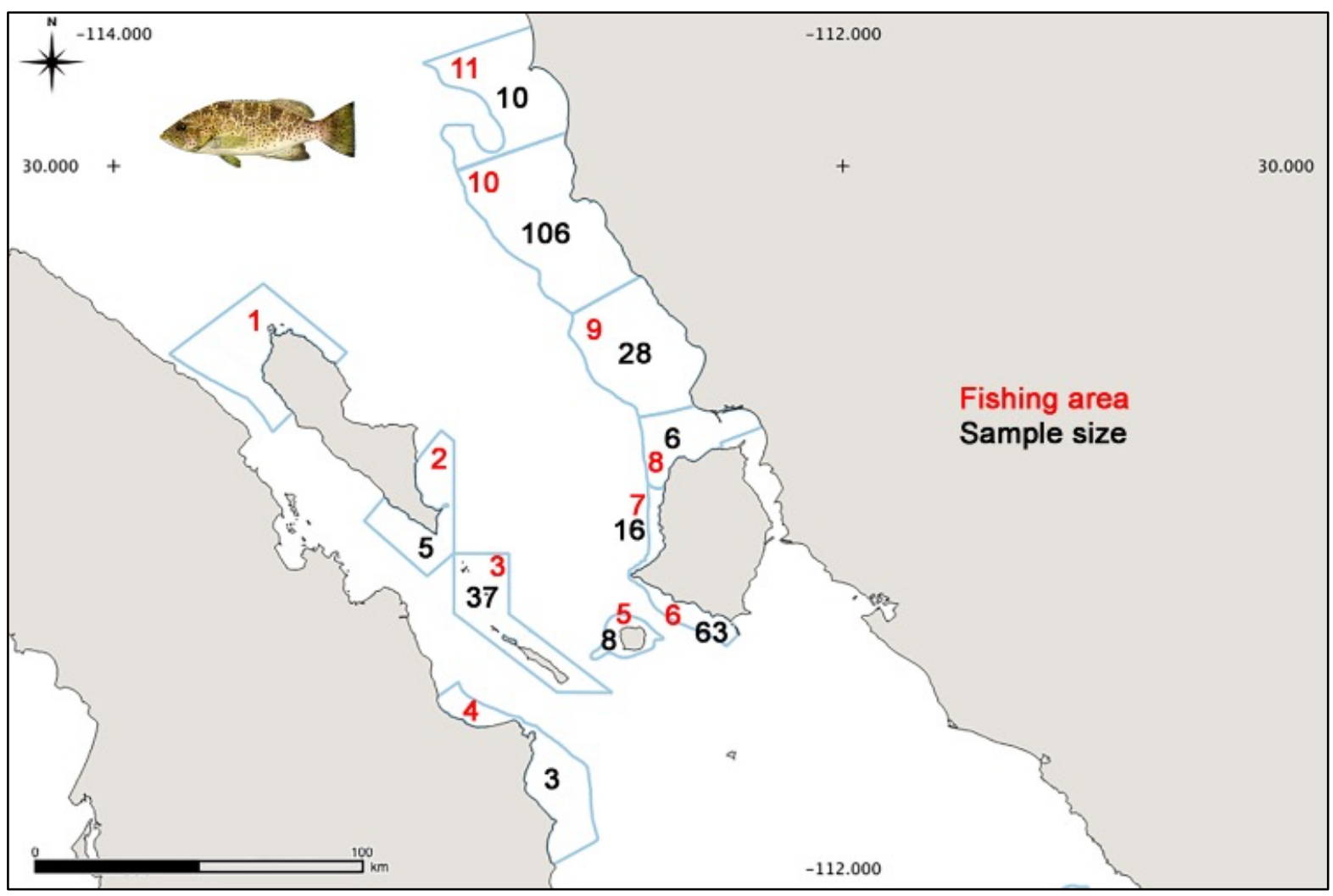




\section{Appendix 5}

Table A5.1 Genepop file with genotypes from 13 microsatellite loci in 282 individuals of leopard grouper.

M12

M29

M32

M03

M27

M7

M18

M17

M22

M25

M11

M5

M26

Pop

FA2, 0207070810100708050619270608030701030404111715260404 FA2, 0811050608130815061006180815050605070507111608180203 FA2, 0608050604141717050523230611050806080410202112120101 FA2, 1518021204051212071208160608040902070103191911160103 FA2, 0208060709131626060914251010070702040206121810160102 Pop

FA3, 0414050707131314061005190411060704060408232314260102 FA3, 1017050706110410050807330914050506070206151912260304 FA3, 1015040405051010060606121011040704050507111815210103 FA3, 0917051005052529081021251112030505070407192004200101 FA3, 0204051004171112061106230309050604060505111515150103 FA3, 1931091005151012111523230607040505070406192121230101 FA3, 0814020404181119050620291111050608110404122123250202 FA3, 0407040410151417081014270811040602040407181815260202 FA3, 0415041205070411070720260000040504050607171808080102 FA3, 0404050803141213081524250811050505070404092304110202 FA3, 1113050907131225081620350611030603040304142215210102 FA3, 0407060805051012050621310710040504090404141719190103 FA3, 0708051210161619101225300000070704040107011510240203 FA3, 0812010605130414091017230610040704090104141714240104 FA3, 0313050504040410051017221010040704050710111914270102 FA3, 1216050604121229051205090717020404050707181913150102 FA3, 0210021106101214081002171013040607090104162303200102 FA3, 0509070814141229031102061015050704070407121424240103 FA3, 0414020404071429060816171014050604040405000009270202 FA3, 1317060608131012051006150610050904060404161822220202 FA3, 0417041012161012062506121016030506090405162217220203 
FA3, 0912020608101314091121220715020405070407011615210304 FA3, 0607020212131415091012270911030604070107172417250206 FA3, 0708040504050812090912210711050702080305172318230101 FA3, 0810060705150420080909240405030504090506022016190202 FA3, 1014020705081114081624340106040407090408131614180101 FA3, 0304050707150418050802211213050504090409182612160102 FA3, 0809040605071717081026280606050605060101162024280209 FA3, 0210071209130809061006160808040505070405011419270101 FA3, 0709060704120808060925250709040602040305212111130102 FA3, 0808050512130414102025281212030505090406152014170102 FA3, 1319060906111216051310160507030402030404142116240204 FA3, 0409040711141113060906210417050605100304122014260102 FA3, 0608041012160812091118291116020704050406081719240102 FA3, 1215040405130414051006170712030505070304182014190102 FA3, 0717070804101013030609170211040506070304162022250204 FA3, 0412050605171012071024270404040506080304121811210202 Pop

FA4, 0511070804050410141428360819050602040505181915150104 FA4, 0416060710140810101519220303000004100104111612320000 FA4, 1013040706141114031109200611060704070505161903170103 Pop

FA5, 0409000005050913112021250407050704050408161610200101 FA5, 1418040705061619031125260812050502070505090919240204 FA5, 0517060707121017111605270707050506070404212114160103 FA5, 1617060705051029061408230308030407070405162013130102 FA5, 1014040612120716091031320410040605080404232421260101 FA5, 0810071109131831051421220709040402040405181817190109 FA5, 0817061107100910051029350915040505070405132014210103 FA5, 0511010605110410071717280111030406070506141517170101 Pop

FA6, 0413050605170811081124290000050708090406021800000203 FA6, 0000000000001016091511180209030402060304182209170203 FA6, 0422050714171012050706250808040505100104000017240204 FA6, 1114050709120728111122230810030403070406161813200104 FA6, 0810020405090910061000000000040604040405182000000101 FA6, 0409060607131316061209180808040507080405171717260203 FA6, 1117020707091213051006200708050604050107181921230104 FA6, 1111040506120414101106170313040704060104091810240104 FA6, 0922040505121213081025310608050601050305111118250102 FA6, 0000020506081112050821250608020503060105172115180106 FA6, 0407060705141019061102200713050605060304011514180104 FA6, 0516051813130114060820230609040603050404202217270102 FA6, 0613050611132628060923311414050902040407152020320202 FA6, 0910050607090914080808250000070805070406202210250101 FA6, 0512040703161314081017180416040505060204161907140102 FA6, 0207020508111227091002060707040702040406182014230102 
FA6, 0821060707131116050902020614040506060304091307190202 FA6, 0811030505061015030600000214050704070106000025300103 FA6, 0507040605060911030622260305040402040404121613170203 FA6, 0613060614151427070909250306040503030404171721390107 FA6, 1315060604060411091521350202040704040404182207130101 FA6, 1010050505110808081016370311050503040406131511210202 FA6, 0814040605121213111116170606040604060305202404240101 FA6, 0815050609130920070923280712030702080408011914260101 FA6, 0210040805051019030916190909030605050304161701210103 FA6, 0508040406120812060820280507040504050405212111220203 FA6, 0608020704140418060813290411040604040404141815190103 FA6, 1022061005070723080908190409050904070405162011270102 FA6, 0307051204121424081108231212030604070510101615150104 FA6, 0215040804070812050927280909040804040404131708310102 FA6, 0102050603071414051121251111040502020204111816210101 FA6, 0613040704140715051108230613040502020505121714200104 FA6, 0916040411121318091222230912050503040409000012170101 FA6, 0813040508161012242817220312050703051017092214200101 FA6, 0410020412121214091300000812010302040505161819190102 FA6, 0810060709111023092901200404040506080507171719240102 FA6, 0513050508111314050817280314040604040304131711180101 FA6, 0410060705090913081009231414050804100304102007180204 FA6, 0413070907131212060706161010030502050505021717170203 FA6, 0505020606101016091006070713050504060304111616250101 FA6, 0914040407140810101017230914050505080610242416240104 FA6, 1011060905100715071024260417040507080404212315250202 FA6, 0507040411160810050614221217050504050407112214140202 FA6, 0407040404161010051008180310050704080404151924240101 FA6, 0809020403080708060724290405050604080405020211220102 FA6, 0505061607120408071505191015050703080305212203030202 FA6, 0810060711150714060815230707040604060204222424240101 FA6, 0410040712160811101119210407040504100104191909260101 FA6, 0919040816170408051119201012050503090304152308190102 FA6, 0214060706121223102308260606030404070407021216220204 FA6, 1014040505091315060720241011040604070407161710140203 FA6, 0809040606091012121322231112030604060304202112120202 FA6, 0203020606120719031005210617050703060105121714210101 FA6, 1317040603140710071117270909050706070304162118220102 FA6, 0207040711180710101406250812050605050109212222270102 FA6, 0717040704160416050917210606040602040304202112160203 FA6, 0509050807070911081802401014050504050505161911140102 FA6, 1013040705141010111502120506030504080405121811110104 FA6, 0813050704180810031620270509020507080410181909180102 FA6, 0408040504060114051023281111050702040505022011200102 FA6, 0408060803111013091007351113030602050306021503120102 FA6, 0716040804070000061113241317050702080103122419190207 
FA6, 0507020811130000011302200309040505080103021615190202 Pop

FA7, 0408050910121213050902230710040504070405122213180202

FA7, 0407041309150414060920250609050507070405182013160103

FA7, 0414080905101319060920210810050502050404222614240202

FA7, 0308020406121212101316201212030505060405162017190202

FA7, 0202020407141011051108210910030403060104131704210101

FA7, 0507040704170414061014200710040407080407011918220204

FA7, 0713040608200818060822250609030402070407202419190102

FA7, 0511040605120413091605120307030507100305191917210202

FA7, 1111041202201214081221250511030405070305202619230102

FA7, 0411050712150814051310260810050605070304212216250103

FA7, 1013030506131213051008190310050604070505192004180108

FA7, 1724040704050815051702060910030304050104171916180202

FA7, 2020040504070000061125310713040702090304182106180101

FA7, 0910050605151014091217190813060707080505142304110304

FA7, 0408040406081319061317270202050602060105181918180102

FA7, 0410050505111420061117170912040705080106191907240104

Pop

FA8, 0814050604110410101206250811050605100202000013230101

FA8, 0507040405131012091008220809050604070304171814250101

FA8, 0608070914170108081202200510040504040405172412190303

FA8, 0419040704070820111321300412050604080405111111250203

FA8, 0917021206131314060617190408060704070305132110190202

FA8, 0212071105061010060808100815040606100304192220240203

Pop

FA9, 0310050812141321010307080609030505070505182121260103

FA9, 0809121205110713081005060812050704070405151803150208

FA9, 0917071304061014030817291012030306070104192216160104

FA9, 0716050506081126051113310408040605060405172312200202

FA9, 1113050715161116050614150609040704050505151604210101

FA9, 0414020204070000111114250811030406070409142015270102

FA9, 1014050804040712121420250407060802060407222316200103

FA9, 0208040606091114101117230606040502100509021705260203

FA9, 1011051305111316060920300506030406070506222411240101

FA9, 0808070706090116091105130408040507130404212619270102

FA9, 0517041305121415111510120000050507100505021914240104

FA9, 0210051805071030050619220208050502050304161813160202

FA9, 1014020503081114091119190811030502070406111811130102

FA9, 0406040604061726051020240608040605080304020216190102

FA9, 0215050602040430101317220912060806070106111909190103

FA9, 0910041603040313192022240708040504070305111811190203

FA9, 0308050708080732060923330212030502040506192114240101

FA9, 0515050704071019111121241010040505060305161719220102

FA9, 1014020503091114091119190811030502070407111811130102

FA9, 0814051605200808121310210203050507080109171812140101 
FA9, 0609040509101010121206131012050704070405132100000101 FA9, 0626060606171214061320201216050706080303132018230203 FA9, 1119040603041011080806290610030502050103121804260102 FA9, 0713031009120415050608250207030802050909181912180104 FA9, 1012040704060828091522330000050708100404222214170102 FA9, 0404040616170417061609281011050504050404212511230106 FA9, 0213060704121012111424390202030605070305112014140102 FA9, 0515061311121517090926380810050507080305021619260202 Pop

FA10, 0510040408091020061616211013030703040305172015180203 FA10, 0718061209201316051021250206030502050404181912220101 FA10, 0405060804050818061025360309040502020404182017170203 FA10, 0913040704130707083022240210040605080406141618200203 FA10, 0814020616181417051502270712050502040104202418240103 FA10, 0818040806071214081006150000050604050404222416220104 FA10, 1114040704131016091425301015020502030505161804210101 FA10, 0517060605060812101019200606050704060405202819190101 FA10, 0710040504060413060906160405030404040405172114270101 FA10, 0814040407090000091022250406050505050304022024240203 FA10, 0419040614140411061320250809020406070405162015200103 FA10, 0512040605091620091616230407050606070505162313160206 FA10, 1013040605121013101315160911030503040304192113220101 FA10, 0205040513140817070816240716050604050607022125250202 FA10, 0515070705121316152322250303050602060404191904270101 FA10, 0219050505121214111314231117050702090303141912120101 FA10, 0211060710122424061108190409050705060104181917230203 FA10, 0410021005121021091521220613070804050411202316230203 FA10, 1216041105171314051013210811030504060404162122280101 FA10, 0814040505051315121402260817040502040404152210240103 FA10, 0221020403150812091518200514030605090407192211180101 FA10, 0510060704060412060824290411030607090405162416200102 FA10, 0405010709161213060912230707050704050404022720200101 FA10, 0206060704140421061021240809050506070404162110220101 FA10, 1117040506080925050606230606030605100304162217220102 FA10, 0924090912171012111529370406040602070304161609140104 FA10, 1111050605120910061215261111040507090303121814190202 FA10, 0313050705170814061416260707050602060105112004150208 FA10, 0411090911130819031119250812050706090404171916200102 FA10, 0507040604050810081006161213050705070507202111190101 FA10, 1213060704081014072614220711040704040505142004190103 FA10, 0307050605180114060919221010040405060406171927270104 FA10, 0610040704161112080934351314030507070405162217170101 FA10, 0912040604160411081006150414030606090405182309110101 FA10, 0811060605120808081002180406050504080104182023230102 FA10, 0215050711110413080906170717050506070304121509150204 FA10, 0412040603030808050902220115040604040303021716160101 
FA10, 0207050911130815111608170606050507080404121514260202 FA10, 0808060706100116091105130408040507130405212619270102 FA10, 0612040504131012030826290000040505060304101910140202 FA10, 0911070707081219060616200311060707080407171824240102 FA10, 0707020516181013091614250519050504060305141416210103 FA10, 0407091204083435050519220409070702050404022212160101 FA10, 0608060604041229050710211112050602040407202210180103 FA10, 0519060713131424060815300314050706070505122116190102 FA10, 2021070904151121101120230910030406060509122111290102 FA10, 1013020503071319091120230613040704080404112009240102 FA10, 0815061204170919070706190909060602050309022117240202 FA10, 0414051105121019051423310811050706070104111115280102 FA10, 0808070706100116091105130408040507130404212619270102 FA10, 0211051003100411051706250812010506060409021816160102 FA10, 0717020703131417101123230000050702050505171918230102 FA10, 0408050604040715111306080910070704060306192010160102 FA10, 0408040612211330081317240309040506080404171827270106 FA10, 0514050708101016051219250407050702070204232511170101 FA10, 0814020405101331091221230609040602050405222517190309 FA10, 0408050903140812091120221414050604090304021809160101 FA10, 0812010803090719111522250000050503040102181809130101 FA10, 0712111203131012070915270209040506090104202207110408 FA10, 1021010605100412091906090000040505070407192200000202 FA10, 1014020503081114091119190811030502070104121811130102 FA10, 0817050605100407060802250310020507080303161900000102 FA10, 0707040601040910091007070309030403100104161622250203 FA10, 0715070705121013101024310808040506070405172016190101 FA10, 0409040512131112070802230408040504040304222200000102 FA10, 0721081207140809081425250610050704070507162007150202 FA10, 0918040603081113091006251014040505100405182110200101 FA10, 0000000000001212050806210808030603100304152522330203 FA10, 0410050508151028101127330406050509100404192007100104 FA10, 1022020604051315091117231120030506100305181909110102 FA10, 0000000000001017030806290206060804040104182111140101 FA10, 0813061006120915080900001111040705090104181808360203 FA10, 1316051011151113112816370000050504100404021720240101 FA10, 1019050704120411030520231111050502040306232616220103 FA10, 0101020908141313061114220711050606060404202104170102 FA10, 0412060614151417060822220000040602050404152309210102 FA10, 0213050613130827081706150809030504100405132813160202 FA10, 0205060604051221011517170107050604050405162004130103 FA10, 0909050712140412121406190511030805070404012111110101 FA10, 0319060606121016141412170610040704070303012014180202 FA10, 0515041313160816080807110913030504040405161704090203 FA10, 0206020404050413111102241012050706060305162315220404 FA10, 0609060813131215080916260617040802070406111810270101 
FA10, 0713041011110415050608250207030802050404181912180104 FA10, 1014020503091114091119190811030502070405121811130101 FA10, 0515070711121414091005170312060602050505022409170102 FA10, 0204020404211220071012120000020302080104021100000107 FA10, 1617020808160715081104160910050607090405151615240103 FA10, 0407070905131013060820350309020505060506161720270102 FA10, 0202040411170813030907200410050605090404192017220202 FA10, 0311050604120410091225270000070704060304162109160102 FA10, 0611070812190407101324240210040804040304181823230203 FA10, 0208040513180407101414200406060706080406172416160103 FA10, 1215060705090713050816200716050704090304192215210101 FA10, 0213050709170413151918240408030504070105192112190101 FA10, 0414021005080111031017190303030704070304162014140101 FA10, 0511040912150910062002170000030505070304232310250101 FA10, 0202040603091414091302240404030504080404181922270101 FA10, 0314060603041428051326260614030507090404020211160206 FA10, 0817040911110810101308250000050501060304122009210202 FA10, 0611040509121014101127300707010405070404171816160102 FA10, 0515050603110410090916161010070807070104181816210101 FA10, 0708020609140827061505201414040504080507171914290102 FA10, 0611040508121014101126300101010405070405171815160102 FA10, 0409040603051439081102230407050504070205132311160101 FA10, 0707060604161213061325250000030504060305192612190102 Pop

FA11, 0209050605051011111506220611040504070404111812190101 FA11, 0408060603091014060802150713050706070404182421250103 FA11, 0910040504040713050806130411050704070306021814140103 FA11, 0507050611121416081113170617040502080404132413190103 FA11, 0810051105150911101117190910040405060405222211240103 FA11, 0611040509121014101127300707010405070000171816160102 FA11, 0810070804151111091317200611040604070507222407140102 FA11, 0611040508121014101127300707010405070404171816160102 FA11, 0308040507080810060823320412050605060304022109200202 FA11, 0510060704060412060824290411030607090405162416200102 


\section{Appendix 6}

Table A6.1 Genetic diversity (average and standard error) observed in leopard grouper individuals sampled at 10 fishing areas, including sample size $(\mathrm{N})$, number of alleles $(\mathrm{Na})$, number of effective alleles (Ne), observed and expected heterozygosity (Ho and He, respectively).

\begin{tabular}{llrrrrr}
\hline Fishing & & \multicolumn{3}{l}{ Na } & \multicolumn{1}{l}{ Ho } \\
\hline FA2 & Mean & 5.000 & 6.923 & 5.916 & 0.815 & 0.822 \\
& SE & 0.000 & 0.383 & 0.377 & 0.036 & 0.013 \\
FA3 & Mean & 36.769 & 15.000 & 9.550 & 0.868 & 0.863 \\
& SE & 0.166 & 1.747 & 1.321 & 0.022 & 0.023 \\
FA4 & Mean & 2.846 & 4.462 & 3.956 & 0.872 & 0.720 \\
& SE & 0.104 & 0.291 & 0.348 & 0.060 & 0.027 \\
FA5 & Mean & 7.923 & 8.385 & 6.482 & 0.808 & 0.798 \\
& SE & 0.077 & 0.859 & 0.878 & 0.052 & 0.032 \\
FA6 & Mean & 61.692 & 16.538 & 10.473 & 0.853 & 0.866 \\
& SE & 0.347 & 1.973 & 1.559 & 0.027 & 0.025 \\
FA7 & Mean & 15.923 & 11.000 & 7.514 & 0.865 & 0.841 \\
& SE & 0.077 & 1.138 & 0.831 & 0.032 & 0.021 \\
FA8 & Mean & 5.923 & 7.385 & 6.224 & 0.869 & 0.812 \\
& SE & 0.077 & 0.712 & 0.690 & 0.051 & 0.022 \\
FA9 & Mean & 27.692 & 14.000 & 9.692 & 0.867 & 0.862 \\
& SE & 0.175 & 1.710 & 1.348 & 0.025 & 0.024 \\
FA10 & Mean & 104.154 & 18.308 & 10.650 & 0.827 & 0.864 \\
& SE & 0.912 & 2.240 & 1.525 & 0.028 & 0.028 \\
FA11 & Mean & 9.923 & 8.385 & 6.011 & 0.866 & 0.800 \\
& SE & 0.077 & 0.828 & 0.702 & 0.037 & 0.028 \\
\hline \multirow{2}{*}{ Total } & Mean & 27.785 & 11.038 & 7.647 & 0.851 & 0.825 \\
& SE & 2.721 & 0.567 & 0.373 & 0.012 & 0.008 \\
\hline
\end{tabular}




\section{Appendix 7}

Statistical analyses conducted with the software UCINET 6.718 comparing the density within and between ecological and social networks and subnetworks.

Table A7.1. $P$ values resulting from the statistical analyses comparing the density between subnetworks. Statistically significant values $(\mathrm{P} \leq 0.05)$ are shown in bold and indicate the two networks being compared have densities that are statistically different from each other.

\begin{tabular}{|c|c|c|c|c|c|c|}
\hline & \multicolumn{2}{|c|}{ Ecological networks } & \multicolumn{2}{|c|}{ Social networks } & \multirow[b]{2}{*}{$\begin{array}{l}\text { Commu } \\
\text { nication }\end{array}$} & \multirow[b]{2}{*}{$\begin{array}{c}\text { Leader } \\
\text { ship }\end{array}$} \\
\hline & Larvae & Migrants & Kinship & Kinship & & \\
\hline BK vs. PL & 0.152 & 0.001 & 0.063 & 0.001 & 0.001 & 0.005 \\
\hline BK vs. All & 0.087 & 0.729 & 0.089 & 0.387 & 0.001 & 0.096 \\
\hline PL vs. All & 0.687 & 0.001 & 0.131 & 0.042 & 0.013 & 0.023 \\
\hline BK vs. BK-PL & 0.001 & 0.093 & 0.058 & 0.008 & 0.001 & 0.001 \\
\hline PL vs. BK-PL & 0.031 & 0.025 & 0.073 & 0.015 & 0.023 & 0.001 \\
\hline All vs. BK-PL & 0.019 & 0.697 & 0.073 & 0.003 & 0.715 & 0.001 \\
\hline
\end{tabular}

Table A7.2. $\mathrm{P}$ values resulting from the statistical analyses comparing the density within ecological and within social networks. Statistically significant values $(\mathrm{P} \leq 0.05)$ are shown in bold and indicate the two networks being compared have densities that are statistically different from each other.

\begin{tabular}{lccc}
\hline Ecological network & BK & PL & All \\
\hline Larvae vs. Migrants & $\mathbf{0 . 0 0 1}$ & 1 & 0.063 \\
Larvae vs. Kinship & $\mathbf{0 . 0 0 1}$ & $\mathbf{0 . 0 0 1}$ & $\mathbf{0 . 0 0 1}$ \\
Migrants vs. Kinship & $\mathbf{0 . 0 0 1}$ & $\mathbf{0 . 0 0 1}$ & $\mathbf{0 . 0 0 1}$ \\
& & & \\
\hline Social network & & & \\
\hline Kinship vs. Communication & $\mathbf{0 . 0 2 5}$ & 0.050 & $\mathbf{0 . 0 0 7}$ \\
Kinship vs. Leadership & $\mathbf{0 . 0 0 1}$ & 0.078 & $\mathbf{0 . 0 0 1}$ \\
Communication vs. & $\mathbf{0 . 0 0 1}$ & 0.668 & 0.334 \\
Leadership & & & \\
\hline
\end{tabular}


Table A7.3. $P$ values resulting from the statistical analyses comparing the density between ecological and social networks. Statistically significant values $(P \leq 0.05)$ are shown in bold and indicate the two networks being compared have densities that are statistically different from each other.

\begin{tabular}{lcccc}
\hline Ecological network & Social network & BK & PL & All \\
\hline Larvae vs. & Kinship & $\mathbf{0 . 0 0 1}$ & $\mathbf{0 . 0 0 1}$ & $\mathbf{0 . 0 0 1}$ \\
& Communication & $\mathbf{0 . 0 0 1}$ & $\mathbf{0 . 0 0 1}$ & $\mathbf{0 . 0 0 1}$ \\
Migrants vs. & Leadership & $\mathbf{0 . 0 0 1}$ & $\mathbf{0 . 0 0 1}$ & $\mathbf{0 . 0 0 1}$ \\
& Kinship & $\mathbf{0 . 0 0 1}$ & $\mathbf{0 . 0 0 1}$ & $\mathbf{0 . 0 0 5}$ \\
& Communication & $\mathbf{0 . 0 0 1}$ & $\mathbf{0 . 0 0 1}$ & $\mathbf{0 . 0 0 8}$ \\
Kinship vs. & Leadership & $\mathbf{0 . 0 0 1}$ & $\mathbf{0 . 0 0 1}$ & $\mathbf{0 . 0 0 5}$ \\
& Kinship & $\mathbf{0 . 0 0 1}$ & $\mathbf{0 . 0 2 5}$ & $\mathbf{0 . 0 0 1}$ \\
& Communication & 0.563 & $\mathbf{0 . 0 0 1}$ & $\mathbf{0 . 0 0 1}$ \\
& Leadership & $\mathbf{0 . 0 0 1}$ & $\mathbf{0 . 0 0 1}$ & $\mathbf{0 . 0 0 1}$ \\
\hline
\end{tabular}




\section{Appendix 8}

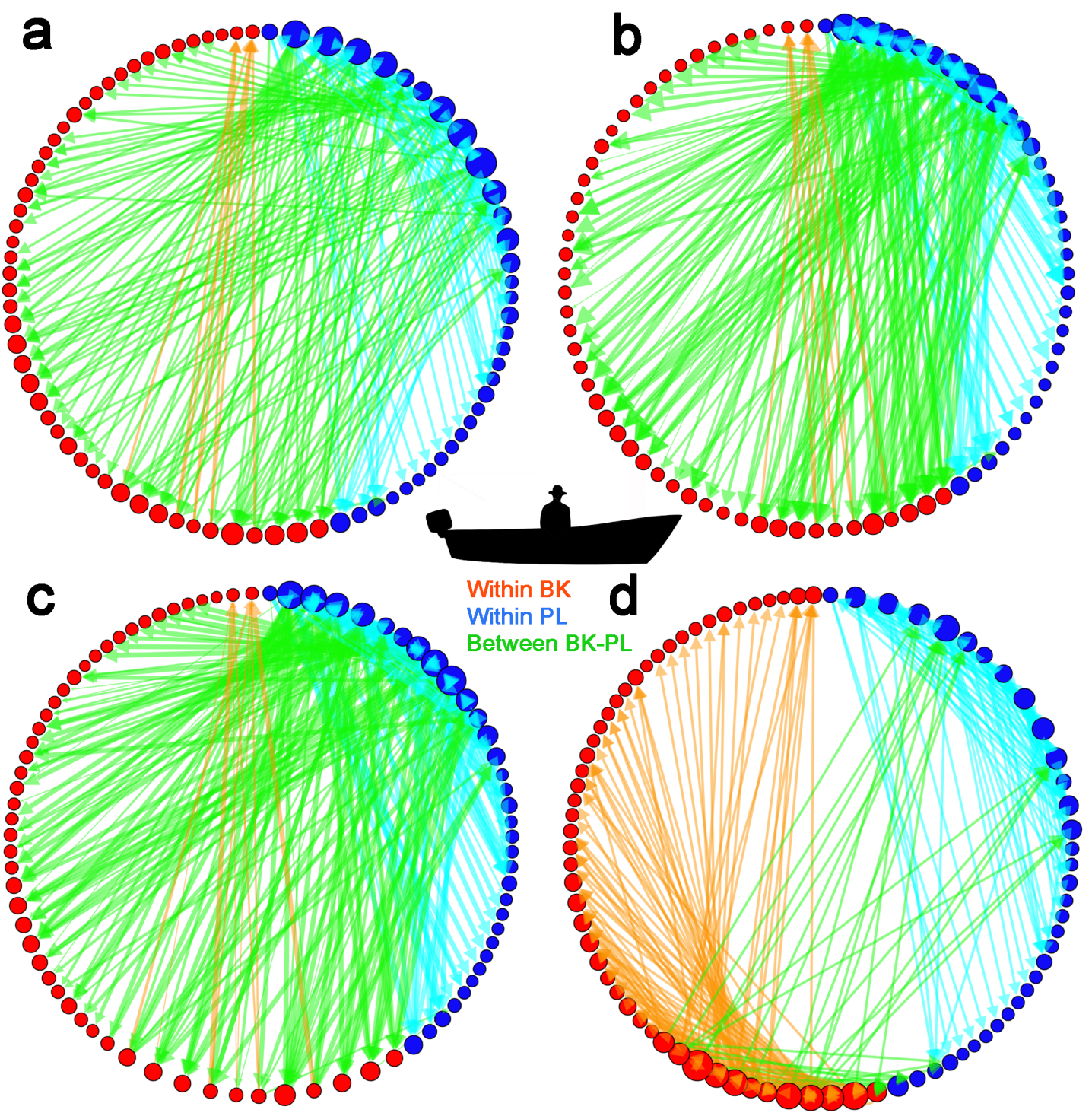

Figure A8.1 Networks describing social connectivity among 83 fishers from two communities in the Northern Gulf of California: a) Communication, b) Trust, c) Reciprocity, d) Leadership. Nodes represent individual fishers colored according to the community to which they belong (Red = Bahia Kino or BK; blue = Puerto Libertad or PL). Node size represents the eigenvector centrality. Links within BK are shown in red, links within PL are shown in blue, and green links represent relationships between the two communities. 